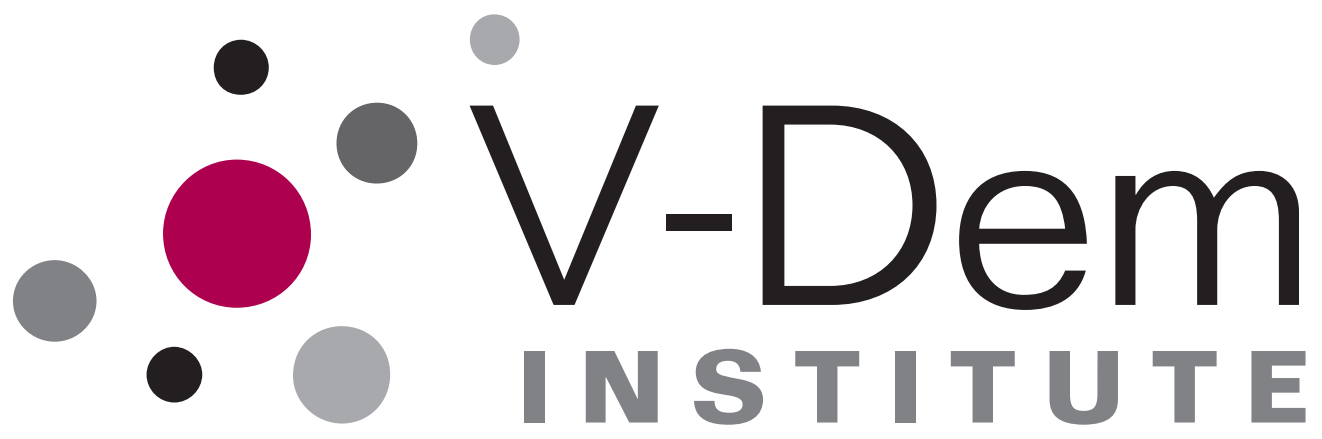

0000000000000000000 000000000000000000000000 0 0000000000000

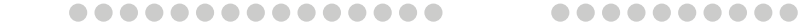

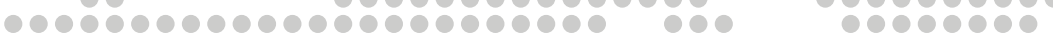

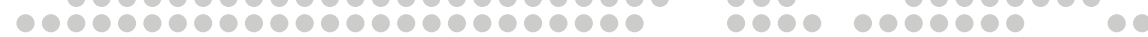

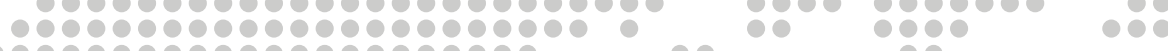

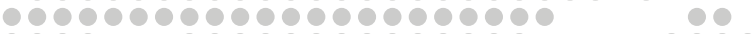

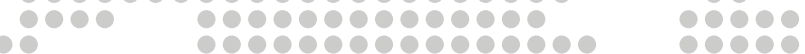
o

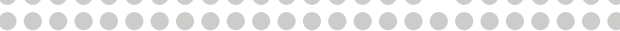

10090

00000

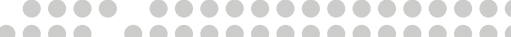

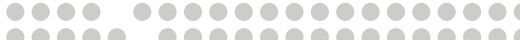
000000000000000000 -

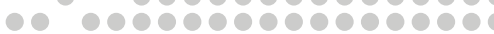
100 ob

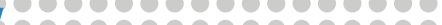

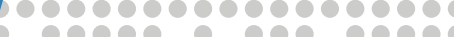

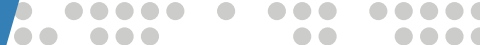

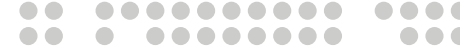

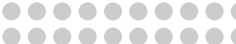

Institutions of Electoral Integrity and Clientelism: The Role of Electoral Management Bodies

Martin Lundstedt Amanda B. Edgell

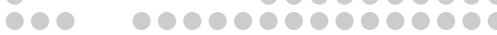


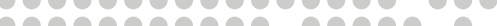

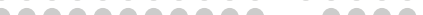

1960?

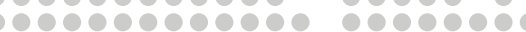
6000000000000

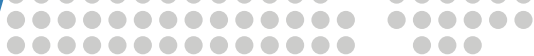

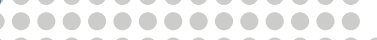
1000000000000000

00000000000000000000

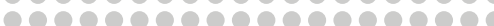

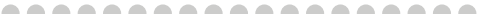

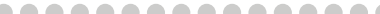
90000000000000 6909090909090

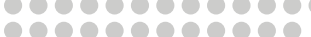

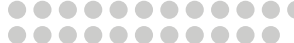
o

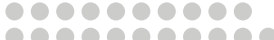
-

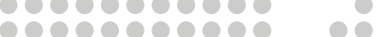

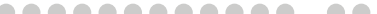
brobrobró

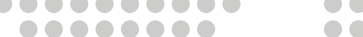

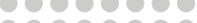

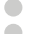
80 8
00000000

-

000000

10000

10000

000

000

10

10

80 o0000000 0000000 000000 000000 1000 00 (

$$
\text { . }
$$


Varieties of Democracy (V-Dem) is a new approach to conceptualization and measurement of democracy. The headquarters - the V-Dem Institute - is based at the University of Gothenburg with 19 staff. The project includes a worldwide team with six Principal Investigators, 14 Project Managers, 30 Regional Managers, 170 Country Coordinators, Research Assistants, and 3,000 Country Experts. The V-Dem project is one of the largest ever social science research-oriented data collection programs.

Please address comments and/or queries for information to:

V-Dem Institute

Department of Political Science

University of Gothenburg

Sprängkullsgatan 19, PO Box 711

SE 40530 Gothenburg

Sweden

E-mail: contact@v-dem.net

V-Dem Working Papers are available in electronic format at www.v-dem.net.

Copyright (C2020 by authors. All rights reserved. 


\title{
Institutions of Electoral Integrity and Clientelism: The Role of Electoral Management Bodies*
}

\author{
Martin Lundstedt \\ Research Assistant \\ V-Dem Institute, University of Gothenburg \\ Amanda B. Edgell \\ Assistant Professor \\ University of Alabama \\ V-Dem Institute
}

\footnotetext{
* Corresponding author: Martin Lundstedt (martin.lundstedt@,v-dem.net). We recognize support by the Knut and Alice Wallenberg Foundation to Wallenberg Academy Fellow Staffan I. Lindberg, Grant 2018.0144; by European Research Council, Grant 724191, PI: Staffan I. Lindberg; as well as by internal grants from the Vice- Chancellor's office, the Dean of the College of Social Sciences, and the Department of Political Science at University of Gothenburg.
} 


\begin{abstract}
While clientelism is most often viewed as a symptom of traditional politics, empirical evidence suggests that it is actually a varied and multifaceted phenomenon, found in widely differing economic, political, and cultural contexts. As a result, our understanding of how formal institutions affect clientelism remains limited. This article integrates research on clientelism and electoral integrity, arguing that as the capacity of electoral management bodies (EMBs) increases, the costs of clientelism increase for voters, parties, and candidates. As a result of this increasing cost, we anticipate that declines in the supply of clientelism are associated with advances in EMB capacity, all else equal. This theory is tested using V-Dem data, covering more than 160 countries from 1900 to 2016, as well as several alternative measures of both EMB capacity and clientelism as vote buying. This multifaceted empirical approach finds strong support for the theory that EMB capacity decreases the supply of clientelism at the country-level.
\end{abstract}




\section{Institutions of electoral integrity and clientelism: The role of electoral management bodies}

Clientelism - the non-programmatic, conditional distribution of resources in return for political support (Stokes et al. 2013) - is a multifaceted phenomenon that can be found in large parts of the developing and developed world, and whose networks, operations, and outreach differ substantially between countries and over time (Hicken 2011; Gans-Morse et al. 2014; Berenschot and Aspinall 2020). As clientelism impedes economic development, democracy, and good governance (e.g. Chubb 1982; Hicken 2011; Stokes 2011), many regard its reduction as an important development goal (Stokes et al. 2013; Berenschot and Aspinall 2020). Yet, past academic research explaining differences in levels of clientelism focus heavily on the effects of modernization (e.g. Kitschelt and Wilkinson 2007; Stokes et al. 2013). In other words, clientelism is thought to be both a cause and outcome of economic development. As a consequence, our knowledge about how formal institutions affect clientelism remains limited. Understanding this could provide insights into more tangible interventions that mitigate against clientelism in the short-run.

To that end, this article integrates research on clientelism with a growing body of work on electoral integrity (e.g. Norris 2015; James et al. 2019) to assess the relationship between electoral management and clientelism. More specifically, we theorize that improving the capacity of electoral management bodies (EMB) will deter clientelism by decreasing its utility for voters, parties, and candidates. By increasing the legitimacy of elections, EMB capacity increases the costs of clientelistic exchanges. Voters increase the price for their votes; thereby encouraging parties and candidates to pursue other strategies to capture support, like programmatic goods. Enhancing EMB capacity also increases the costs of clientelism for parties and candidates by impeding the monitoring capacity of their brokers, e.g. by ensuring ballot secrecy and limiting access to polling stations.

We assess the relationship between electoral management and the supply of clientelism within countries over time. The main tests draw on data collected by the Varieties of Democracy (V-Dem) Project using a sample of more than 160 countries from 1900-2016. The empirical investigation also includes several alternative measures of EMB capacity and clientelism to account for risks of measurement bias. Because endogeneity is prevalent with two such proximate phenomena, this article employs three strategies: one- and five-year lags of the independent variable, an instrumental variable model, and a model treating endogeneity as omitted variable bias, namely corruption. This multifaceted assessment of the country-level 
relationship supports the theory that EMB capacity decreases the supply of clientelism. However, the robustness checks suggest that only certain elements of EMB capacity and clientelism could be related, paving the way for future research into more specific institutional and behavioral causal mechanisms.

The findings hold several implications for research on clientelism and electoral integrity. We demonstrate the importance of analyzing formal institutions and their performance when addressing clientelism, from both an academic and practice perspective. Moreover, we provide evidence that the effects of EMB capacity resonate beyond formal democratic procedures, altering the incentives and behavior of various political actors. Thus, our findings link to the broader question on the relationship between democracy and good governance, showing how the improvement of a democratic institution can deter a practice that undermines impartiality and administrative efficiency. Finally, while the existing literature focuses on a set of dynamic, longer term effects stemming from economic development, this article offers an analysis of a more direct and practical method of deterring clientelism. Improving the capacity of electoral management bodies, while not a simple task, is a clear goal, and furthermore one that the development community already has thorough experience working toward (e.g. Catt et al. 2014; Norris 2015; Karp et al. 2017).

\section{Clientelism - many varieties, few detriments}

Clientelism is defined as a non-programmatic, conditional distribution of resources like jobs, goods, services, and money, that are given in exchange for political support (Stokes et al. 2013). In other words, it is a targeted, partial distribution contingent on reciprocating political support that is neither formalized nor public. This typically operates through a pyramidical network of brokers charged with persuading or threatening voters with resources (Stokes 2005; Nichter 2008; Stokes et al. 2013). Brokers thus play an important role in clientelistic exchanges, but also present several inefficiencies for parties, such as embezzlement, moral hazard, and insufficient monitoring capacity (Stokes et al. 2013; Aspinall 2014; Denissen 2020). There is also widespread agreement that pervasive clientelism leads to democratic, institutional, and distributary deficiencies that play a part in keeping countries unequal, corrupt, and poor (Chubb 1982; Shefter 1994; Kitschelt and Wilkinson 2007; Hicken 2011; Fukuyama 2013; Stokes et al. 2013).

Aside from these commonalities, however, clientelism is often characterized as multifaceted and heterogenous, as is shown by the extensive case study literature covering most world regions and time periods (e.g. Chubb 1982; Shefter 1994; Weghorst and Lindberg 2011, 
2013; Stokes et al. 2013; Aspinall and Hicken 2020; Denissen 2020; Veenendal and Corbet 2020; Weiss 2020). For example, some scholars contend that clientelism necessarily requires an exchange between two individuals sharing a close relationship (dyarchy) that is asymmetrical in terms of power and status (hierarchy) and sustained over repeated exchanges (iteration). In the recent decade, however, studies suggest that clientelism varies in relation to these three components (e.g. Nichter 2011; Gans-Morse et al. 2014; Berenschott and Aspinall 2020; Y1ldırım and Kitschelt 2020). Some clientelism, often termed "relational", is more iterated, dyadic, and hierarchic, a typical case being a civil service job being given in exchange for political support. By contrast, "electoral" clientelism frequently entails a "single-shot" of vote-buying at election time, often without any elements of dyarchy or iteration between broker and voter.

This heterogeneity could be a consequence of limited comparative data and divergent case contexts. In response, several scholars have developed frameworks describing the "varieties of clientelism” (e.g. Gans-Morse et al. 2014; Mares and Young 2016; Berenschot and Aspinall 2020) based on contextual factors that incentivize some forms of clientelism over others and actors' strategies that determine the more precise set of exchanges within those contextual boundaries.

Several contextual factors may shape the choice of clientelistic strategies. For example, in African countries, democratization shifts clientelism from personalized elite-centered exchanges toward mass-based practices (Van de Walle 2007). Elsewhere, evidence shows that vote-buying increases in young electoral regimes (Van Ham and Lindberg 2015a) and that clientelistic broker mediation differs between democracies and autocracies (Denissen 2020). Furthermore, demographic factors like population size (Veenendal and Corbet 2020) and ethnic identities (Posner 2005; Isaksson and Bigsten 2017) shape the type of clientelistic networks and targets of inducements. In addition, economic development (Kitschelt and Wilkinson 2007; Stokes et al. 2013), degree of competition (Chubb 1982; Magaloni et al. 2007; Medina and Stokes 2007; Driscoll 2018; Y1ldırım 2020), and institutions and institutional junctures (Fukuyama 2013; Aspinall and Hicken 2020; Driscoll 2020), are all likely to affect the type of clientelistic operations observed within a given case.

Operating within these contexts, actors may choose from a menu of clientelism strategies based on their perceived costs and viability for success (Mares and Young 2016). For example, in electoral clientelism, parties can opt for varying combinations of vote buying, turnout buying, abstention buying, and combined persuasions (Nichter 2008; Gans-Morse et al. 2014). For relational clientelism, there are several types of inducements available, such as handing out employment, contracts, and long-term provision of some service (e.g. Chubb 1982; Shefter 1994; Robinson and Verdier 2013). Game theoretical models on clientelism highlight that different 
groups of voters generally demand different resources and monitoring (Dixit and Londregan 1996; Calvo and Murillo 2004; Stokes 2005; Nichter 2008; Stokes et al. 2013), further contributing to parties choosing a different portfolio of clientelistic practices depending on circumstances. Consequently, the degree, type, and particular operations of clientelism in a given country and time period are the product of a number of contextual factors and actors' choices that can result in widely differing clientelistic systems.

The variation and complexity of modern-day clientelism suggest that several variables could explain its observed supply within a given context. Yet, to date, our knowledge about the origins and extent of clientelism remains dominated by modernization theory (Calvo and Murillo 2004; Kitschelt and Wilkinson 2007; Stokes 2011; Hicken 2011; Robinson and Verdier 2013; Stokes et al. 2013). This theory generally relies on three propositions: First, increased income levels make support costlier to buy, thus decreasing parties' and candidates' propensity to supply clientelistic goods (Kitschelt and Wilkinson 2007; Hicken 2011; Stokes et al. 2013). Second, increased income levels shift voters' preferences toward new types of benefits, generally those linked to public goods and further development of the national economy, thus decreasing voter demand for clientelism (Hicken 2011). Finally, economic development causes urbanization, which obstructs brokers capacity to keep small, stable networks of clients (Stokes et al. 2013). Consequently, poverty reduction, a growth in the middle class, and greater urbanization - factors frequently tied to economic development and modernization - are seen as the central impediments to clientelistic practices.

This characterization of clientelism as a pre-modern practice that will fade with economic development remains at odds with the rich case-based evidence showing clientelism to be a persistent phenomenon, adaptable to changing circumstances within widely differing economic, political, and cultural contexts (Hicken 2011; Berenschot and Aspinall 2020). As such, several recent studies explore how clientelism relates to other factors. For example, evidence from Ghana shows that clientelistic practices decrease over the experience of iterated elections (Lindberg 2010, 2013; Weghorst and Lindberg 2011, 2013), as women's participation increases, and due to democratic education campaigns (Vicente and Wantchekon 2009). Parties and politicians may also decrease their clientelistic exchanges as their capacity for credible commitment increases, which is shown to be related the age of democracy (Keefer 2007; Keefer and Vlaicu 2008) ${ }^{2}$ and voter trust in bureaucracies (Bustikova and Corduneanu-Huci 2017). Other studies link clientelism to the viability of programmatic campaigns (Keefer 2007;

\footnotetext{
${ }^{2}$ Kitschelt and Kselman (2013) find that age of democracy may moderate the effects of economic development; although, this study argues that economic development and linkage to the international economy are more important predictors than regime type.
} 
Robinson and Verdier 2013; Kitschelt and Kselman 2013; Van Ham and Lindberg 2015a; Bustikova and Corduneanu-Huci 2017), degree of party system competition (Magaloni et al. 2007; Medina and Stokes 2007; Driscoll 2018; Yıldırım 2020), level of ethnic fractionalization (Easterly and Levine 1997; Posner 2005; Chandra 2007; Baldwin and Huber 2010), and dysfunctional institutions and governance (Acemoglu and Robinson 2010; 2012; Rothstein 2011; 2018; Fukuyama 2013). These findings suggest that economic development is unlikely to be the only avenue through which clientelism decreases. They call for a more concerted effort to theorize about how formal institutions and other aspects of the political context generally affect the supply of (and demand for) clientelism.

\section{Electoral management's impact on actors' political strategies}

Formal institutions are widely regarded to shape political outcomes by setting constraints and incentives for involved actors (Dahl 1971; North 1991; Miller and Hammond 1994; Helmke and Levitsky 2004). In particular, electoral systems, rules, and procedures often affect political behavior (e.g. Norris 2004; 2009; Schedler 2009a, b; Lindberg 2009a, b; Brownlee 2009; Lijphart 2012; Edgell et al. 2018). These institutions are especially likely to alter actors' preferences for clientelism because a substantial amount of clientelistic exchanges occur during and with the motive of winning elections. Focusing on one aspect of this and drawing on the growing literature on electoral integrity, this article explores the role of electoral management in clientelism.

Electoral management is often an important determinant of electoral integrity, democratization, and democratic resilience (Mozaffar 2002; Mozaffar and Schedler 2002; Elklit and Reynolds 2002; 2005; Norris 2015, 2019; James et al. 2019; van Ham and Garnett 2019;

Garnett 2019). National elections constitute a massive mobilization of people, which produces a complex logistical exercise that includes enforcing electoral and campaign rules, setting up and staffing polling stations, administering ballots, establishing and updating voter rolls, counting the votes, and distributing information on when, where, and how to vote (Mozaffar 2002; Mozaffar and Schedler 2002; Elklit and Reynolds 2002; 2005; Norris 2015; James et al. 2019). There are numerous examples in both developed and developing countries where the electoral management has failed to meet these demands, among the most famous being the chaotic events in Florida in the 2000 U.S. presidential election (Mozaffar and Schedler 2002). The recent Iowa caucus for the 2020 U.S. Democratic Party presidential primary also aptly illustrates the consequences of poor electoral management, where the technical system to tally the votes broke 
down, causing much delay, confusion, and distrust (Cohn et al. 2020; McNamara 2020; Seitz and Klepper 2020).

As a result, electoral integrity relies on a capable electoral management body (EMB), the formal organization responsible for implementing electoral procedures. While EMBs can vary considerably in terms of governance, composition, and methods, James et al. (2019) outline three sets of tasks that are common to all EMBs: organizing, monitoring, and certifying elections. Studies on EMBs address, for example, the importance of staffing (James 2019), budget (Clark 2019), capacity (Garnett 2019), and, most frequently, autonomy (Mozaffar 2002; Birch 2008; Hartlyn et al. 2008; van Ham and Lindberg 2015b; Kerr and Lürhmann 2017; van Ham and Garnett 2019). In the majority of studies, these aspects of EMBs exhibit important effects on the quality of elections and democracy. Consequently, the improvement of EMB performance and independence is now regarded as an important development goal (Catt et al. 2014; Norris 2015; Karp et al. 2017).

The focus of this article is on the capacity of the EMB, meaning their "ability to perform functions and achieve their goals" (Garnett 2019). As Mozaffar and Schedler (2002) note, elections always have a "margin of error" based on the degree of inaccuracies and deficiencies. Some of the most notable issues include delayed, incorrect, or insufficient ballot papers; poorly trained poll workers; dead people listed on the voter roll; legitimate voters turned away; voting machines breaking down; broken ballot box seals; and long waiting times (Norris 2015, p. 133). The size of this margin of error depends on the EMB's capacity to coordinate, staff, and organize the electoral procedure. This in turn depends on competency, financing, and efficiency.

The role of electoral management bodies (EMBs) at preventing or reducing clientelism has gone largely unnoticed in both the literature on electoral integrity and clientelism. This is surprising considering the proximity of the two phenomena and the large investments in capacity building for electoral management and administration by the donor community. Clientelism is likely to be affected by factors that improve other components of electoral integrity, and achieving electoral integrity is dependent on deterring clientelistic practices. For example, related research on corruption and good governance shows a relatively modest effect of economic development (e.g. Rothstein 2011; 2018; Fukuyama 2013), arguing instead for the importance of building capable and impartial institutions (Acemoglu and Robinson 2010; 2012).

Moreover, by directly affecting whether electoral rules and procedures are upheld, EMB capacity is likely to alter the perceptions and behavior of political agents. First, EMB capacity matters for the credibility of elections (Mozaffar and Schedler 2002; Birch 2011; Kerr 2014; Bowler et al. 2015; Norris 2015, 2019). Where capacity is high, EMBs provide the procedural 
certainty necessary for the substantive uncertainty of free and fair elections (Mozaffar and Schedler 2002). Second, EMBs are an easily identifiable institution with which parties' and voters' have direct experiences leading up to and on election day (Mozaffar 2002; Elklit and Reynolds 2002, 2005; Birch 2011; Kerr 2018). Party officials are likely to be very aware of an electoral process ridden with irregularities and incompetence, as this will incidentally either benefit or harm them. This also affects what is available to them on the "menu of manipulation" (Schedler 2002). Voters, in turn, will be informed of EMB performance before and after elections from their own experiences, alongside reporting by media, parties, and civil society organizations (Kerr 2014, 2018; Kerr and Lürhmann 2017). In short, where EMBs lack the capacity to organize elections efficiently, this leads to distrust in the electoral process and a loss of legitimacy for the state institutions. This can have a direct bearing on clientelistic strategies of voters, parties, and candidates.

\section{Theorizing the relationship between EMB capacity and clientelism}

Clientelism involves both costs and benefits for involved actors and that cost-benefit calculation affects both the supply of and demand for clientelistic politics. We theorize that EMB capacity moderates this calculation for voters, parties, and candidates by increasing the legitimacy of elections.

\section{Voters}

Voters benefit from clientelism through resources - including money, in-kind gifts, and other valuable goods or services - given in return for political support. The cost to voters includes reduced opportunities to voice a genuine preference, to have an impact on political decisions, and generally, to access political representation. Political actions, be it casting a ballot or working for a party, are instead done in exchange for a clientelistic good, and should voters take actions that counter the intent of the clientelistic good, they may be punished by having valuable resources withdrawn in the future. ${ }^{3}$

EMB capacity alters this cost-calculation through its effect on the degree of trust voters have in elections as procedures that genuinely determine who governs. Electoral processes marred with irregularities, incompetence, limited information, and understaffed polling stations

\footnotetext{
${ }^{3}$ Note that this reasoning serves as the baseline for developmentalist approaches as well. As voters' income increases, their interests and stakes in national political decisions increase, and the costs of not supporting one's preferred party also increase.
} 
that are few and far between reduce voters' trust in the meaningfulness of electoral procedures, thereby undermining their ability to voice preferences, impact political decisions, and access political representation. In such settings, the opportunities for clientelistic behavior are rife because the perceived cost to voters is very low. There is little reason for voters to refuse clientelistic benefits in exchange for campaigning or voting for a specific party or candidate in an electoral procedure they do not believe functions. As EMB capacity increases, however, so does the alternative cost to voters of not voicing their genuine preference and supporting their preferred party or candidate. In practical terms, this means that the amount of people who refuse clientelistic exchanges increases with EMB capacity, and those still inclined to sell some political support should demand more expensive goods or services in return. All else equal, therefore, the higher the EMB capacity, the lower the demand for clientelism from voters and the higher the costs for parties.

\section{Parties and candidates}

For parties and candidates, the benefits of clientelistic exchanges consist of securing electoral and political support. The costs are primarily the resources it takes to finance the clientelistic pyramid, but also the costs of engaging in an unscrupulous or illicit activity. EMB capacity affects this cost-calculation by shaping how expensive the clientelistic pyramid is and how reliable it is at securing support.

Presumably, underfinanced and understaffed EMBs will have a hard time upholding ballot secrecy, staff impartiality, and competency, offering numerous opportunities for brokers to either directly or indirectly monitor voters. As EMB capacity increases, however, two things happen. First, brokers require more sophisticated and expensive methods to monitor compliance, or alternatively, must shift their focus from swing voters to already loyal ones. Either way, this increases the costs of clientelism for parties and candidates. Second, due to less monitoring capacity, voters have less reason to fear individual punishment for reneging on their promise. Therefore, the incentive to accept clientelistic benefits without following through on the commitment will increase, which increases the risk, and thus the cost, for parties and candidates. While this effect is restricted to vote-buying in its direct terms, it should spill over to all clientelistic practices, since vote buying can be regarded as the bread and butter of clientelism. If the larger system of clientelistic exchanges and networks does not produce electoral support in the end, there is little incentive to keep it. Consequently, increases in EMB capacity will increase the costs of clientelism for parties and candidates, all else equal. The theory is depicted in full in Figure 1. 


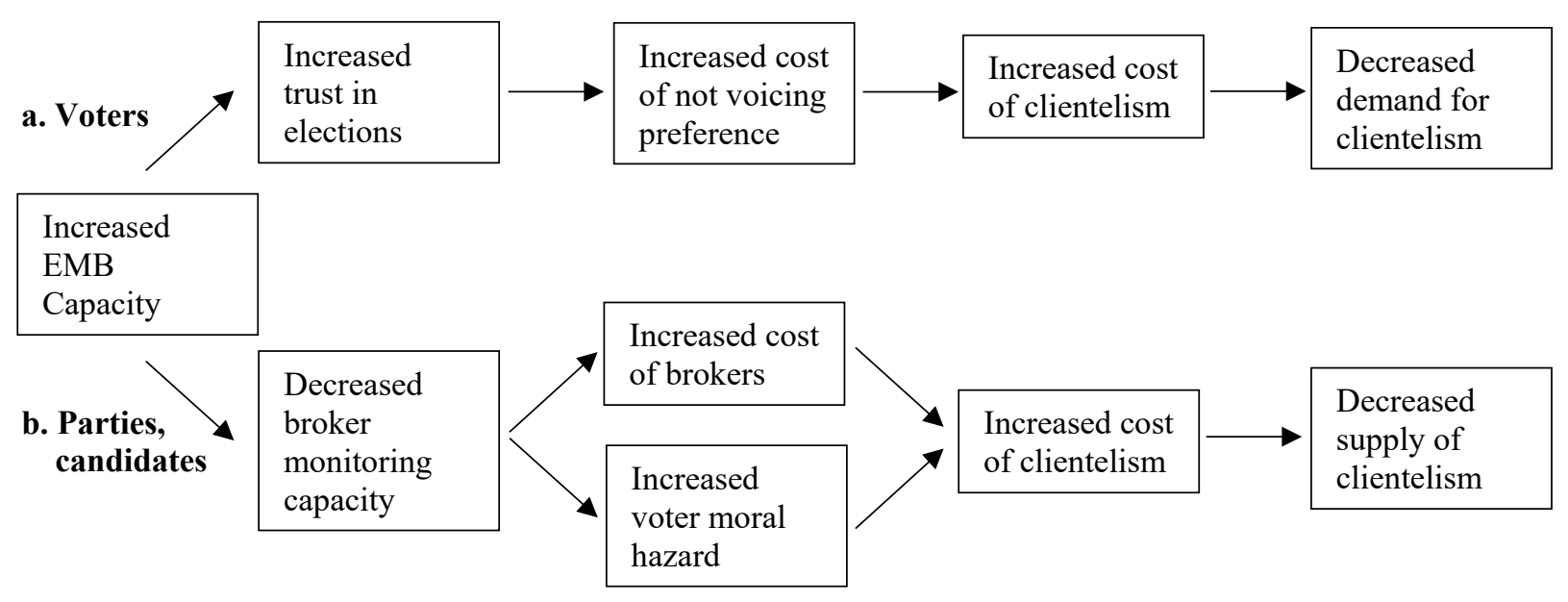

Figure 1. Theoretical Model.

\section{Measuring Clientelism and EMB Capacity}

As our primary test of the theory, we use data collected by the V-Dem Project, a world-leading expert survey covering over 450 indicators from 1789-2019 for most of the world's political units (Pemstein et al. 2019; Coppedge et al. 2020a). V-Dem defines clientelism as relationships that "include the targeted, contingent distribution of resources (goods, services, jobs, money, etc) in exchange for political support" (Coppedge et al. 2020b, p. 273), which corresponds well to the conceptualization of a non-programmatic, contingent distribution of resources.

As our main dependent variable, the V-Dem clientelism index (v2xnp_client) captures the extent to which politics is based on clientelistic relationships (Sigman and Lindberg 2017). The index ranges from zero (low clientelism) to one (high clientelism). It is constructed from three underlying indicators: the extent of vote- and turnout buying (v2elvotbuy), clientelistic party-voter linkages (v2psprlnks), and particularistic government spending (v2dlencmps). ${ }^{4}$ These three components are not exhaustive of clientelistic practices, and the particularistic component to some extent includes related but separate practices like pork barrel spending. Nevertheless, the measure offers the most comprehensive data on clientelism presently available, reflecting both electoral and relational forms of clientelism. We test for aggregate effects of the EMB on overall

\footnotetext{
${ }^{4}$ For these three components of clientelism (v2elvotbuy, v2psprlnks, v2dlencmps) the scales have been reversed so that they go from low to high clientelism.
} 
levels of clientelism using the clientelism index, as well as, its effects on each of the types of clientelism that make up the index.

V-Dem also has a direct measure of EMB capacity, based on the question "Does the Election Management Body (EMB) have sufficient staff and resources to administer a well-run national election?” (Coppedge et al. 2020b, p. 62), which aligns with the above reviewed definition. This indicator serves as our main independent variable of interest.

\section{Mitigating concerns about measurement bias}

Because the same experts may code values for both clientelism and EMB capacity on the V-Dem survey, this introduces some risk of circularity in the measurement. An expert's view or knowledge of clientelism could certainly influence her assessment of EMB capacity, or vice versa. In addition, previous answers on one aspect of electoral integrity could prime the coder into answering an aligning answer to a later question. Consequently, there is a potential measurement bias of unknown direction and magnitude.

To mitigate concerns of measurement bias, we test the robustness of our findings from the V-Dem data using a number of alternative measures of clientelism and EMB capacity. Because these alternative measures differ considerably, we evaluate their results based on two criteria. First, as any empirical inference hinges on having a valid measurement of the concept (King et al. 1994; Adcock and Collier 2001), the measurement's proximity to EMB capacity or clientelism as conceptualized by V-Dem determines how equipped it is at evaluating the degree of bias in the V-Dem measure. Second, to maximize comparison with the V-Dem estimations, sample sizes should be as similar as possible in the alternative measures, otherwise differences in the results could be due to sampling issues.

To that end, we use four additional measures of EMB capacity. First, the Electoral Integrity Project runs the Perceptions of Electoral Integrity (PEI) survey, which is an expert survey that assesses a range of electoral factors at election years for over 150 countries since 2012 (Norris 2015; Norris and Grömping 2019). The PEI index on the quality of electoral procedures consists of four dimensions: management quality, voter information, fair officials, and whether elections are run in accordance with the law. ${ }^{5}$ This fits well with the concept of EMB capacity, and the extensive spatial coverage makes the PEI a good robustness check. Second, Kelley (2012) has gathered data on pre-election and election day electoral management quality through coding electoral reports on 146 countries between 1978-2004. This measure also has high validity and good country-year coverage, making it a valuable robustness check. Third,

\footnotetext{
${ }^{5}$ This variable is rescaled to run from 1 to 10 instead of its original scale of 1 to 100 .
} 
Table 1. Measures of EMB capacity

\begin{tabular}{|c|c|c|c|c|c|}
\hline & V-Dem & PEI & QED & QED & Garnett \\
\hline Measure & $\begin{array}{l}\text { EMB Capacity: } \\
\text { Does the Election } \\
\text { Management Body } \\
\text { (EMB) have sufficient } \\
\text { staff and resources to } \\
\text { administer a well-run } \\
\text { national election? }\end{array}$ & $\begin{array}{l}\text { Electoral procedures } \\
\text { index: } \\
\text { Additive scale of the } \\
\text { four components } \\
\text { Elections were well } \\
\text { managed; Information } \\
\text { about voting procedures } \\
\text { was widely available; } \\
\text { Election officials were } \\
\text { fair; Elections were } \\
\text { conducted in } \\
\text { accordance with the law. }\end{array}$ & $\begin{array}{l}\text { Overall pre-election } \\
\text { administrative } \\
\text { capacity: } \\
\text { Captures problems with } \\
\text { administration, } \\
\text { commission, voter } \\
\text { information and } \\
\text { violence in the period } \\
\text { before the election }\end{array}$ & $\begin{array}{l}\text { Election day } \\
\text { administrative } \\
\text { capacity: } \\
\text { Captures problems with } \\
\text { administration, logistics, } \\
\text { information and staff } \\
\text { during election day. }\end{array}$ & $\begin{array}{l}\text { EMB Capacity: } \\
\text { Capacity score based on } \\
14 \text { items divided into } \\
\text { four groups: results, } \\
\text { personnel, information } \\
\text { for voters and } \\
\text { communication. }\end{array}$ \\
\hline Methodology & Expert survey & Expert Survey & $\begin{array}{c}\text { Coding based on } \\
\text { Country Reports on } \\
\text { Human Rights Practices }\end{array}$ & $\begin{array}{c}\text { Coding based on } \\
\text { Country Reports on } \\
\text { Human Rights Practices }\end{array}$ & $\begin{array}{c}\text { Observational data on } \\
\text { EMB websites }\end{array}$ \\
\hline Coverage & $\begin{array}{l}163 \text { countries, } 1900- \\
2016\end{array}$ & 153 countries, 2012-16 & $\begin{array}{l}146 \text { countries, } 1978- \\
2004\end{array}$ & $\begin{array}{l}146 \text { countries, } 1978- \\
2004\end{array}$ & 92 countries, 2015 \\
\hline
\end{tabular}

Garnett (2019) has compiled observational data on EMB capacity for 99 countries in 2015 based on EMB website analysis. Website analysis restricts the sample to those that have such a website in the given year making the coverage comparatively limited, and it is not a direct assessment of capacity, but acts as a solid proxy. ${ }^{6}$ The measurements on EMB capacity are summarized in Table 1, including country-year coverage when adjusted to the V-Dem sample frame.

As alternatives for the dependent variable, we draw on three different datasets with measures of vote buying. First, we use the Index of Electoral Malpractice (IEM) compiled by Birch (2011), which measures the extent of vote buying through electoral reports in 58 "new and semi-democracies" between 1995-2007. While the sample only includes certain types of regimes, the IEM does have a fair degree of spatial coverage over a period of time. Second, we draw on two citizen survey datasets, the Afrobarometer and the World Value Survey (WVS). In the Afrobarometer (2013) round 5, respondents in 34 African countries were asked how often they had been offered a bribe in return for their vote. In round 6 of the Afrobarometer (2015), respondents in 36 countries where asked how often they believe that voters are bribed. The same question was asked in WVS wave six (Inglehart et al. 2014), to respondents in 42 countries across the world. These survey data only assess the experience of being asked bribes, not taking them, and the perceptions of vote-buying, which can differ considerably from the reality. Furthermore, the coverage is restricted compared to other measures used in these robustness checks. However, surveys do offer a view from the ground that is lacking in the other datasets, and a regular citizen might very well be just as knowledgeable of clientelism as an expert coder (e.g. Charron 2016). In sum, while neither of these alternative measures fully capture clientelism, and coverage is comparatively limited, they do offer additional perspectives on vote buying, one important element of clientelism that is most proximally affected by EMB capacity in our theory.

\footnotetext{
${ }^{6}$ Correlation between this measure and V-Dem as reported in Garnett (2019) is 0.43.
} 
Table 2. Measures of clientelism

\begin{tabular}{|c|c|c|c|c|c|c|c|c|}
\hline & V-Dem & V-Dem & V-Dem & V-Dem & IEM & Afrobarometer & Afrobarometer & WVS \\
\hline Measure & $\begin{array}{l}\text { Clientelism } \\
\text { Index: } \\
\text { To what extent are } \\
\text { politics based on } \\
\text { clientelistic } \\
\text { relationships? }\end{array}$ & $\begin{array}{l}\text { Vote buying: } \\
\text { In this national } \\
\text { election, was there } \\
\text { evidence of vote } \\
\text { and/or turnout } \\
\text { buying? }\end{array}$ & $\begin{array}{l}\text { Party-voter } \\
\text { linkages: } \\
\text { Among the major } \\
\text { parties, what is the } \\
\text { main or most } \\
\text { common form of } \\
\text { linkage to their } \\
\text { constituents? }\end{array}$ & $\begin{array}{l}\text { Particularistic } \\
\text { spending: } \\
\text { Considering the } \\
\text { profile of social and } \\
\text { infrastructural } \\
\text { spending in the } \\
\text { national budget, how } \\
\text { "particularistic" or } \\
\text { "public goods" are } \\
\text { most expenditures? }\end{array}$ & $\begin{array}{l}\text { Reports on Vote } \\
\text { Buying: Was } \\
\text { vote-buying } \\
\text { observed? }\end{array}$ & $\begin{array}{l}\text { Experience of } \\
\text { Vote Buying: } \\
\text { How often, if ever } \\
\text { did a candidate or } \\
\text { someone from a } \\
\text { political party offer } \\
\text { you something, like } \\
\text { food or a gift or } \\
\text { money, in return } \\
\text { for your vote? }\end{array}$ & $\begin{array}{l}\text { Perceptions of } \\
\text { Vote Buying: } \\
\text { In your opinion, } \\
\text { how often do the } \\
\text { following things } \\
\text { occur in this } \\
\text { country's elections: } \\
\text { Voters are bribed }\end{array}$ & $\begin{array}{l}\text { Perceptions of } \\
\text { Vote Buying: } \\
\text { In your opinion, } \\
\text { how often do the } \\
\text { following things } \\
\text { occur in this } \\
\text { country's elections: } \\
\text { Voters are bribed }\end{array}$ \\
\hline Methodology & Expert survey & Expert survey & Expert survey & Expert survey & $\begin{array}{l}\text { Expert coding of } \\
\text { electoral reports }\end{array}$ & Citizen survey & Citizen survey & Citizen survey \\
\hline Coverage & $\begin{array}{c}163 \text { countries, } \\
1900-2016\end{array}$ & $\begin{array}{c}161 \text { countries, } \\
1900-2016\end{array}$ & $\begin{array}{c}163 \text { countries, } \\
1900-2016\end{array}$ & $\begin{array}{c}163 \text { countries, } \\
1900-2016\end{array}$ & $\begin{array}{c}58 \text { countries, } \\
1995-2007 \\
\end{array}$ & $\begin{array}{c}34 \text { countries, } \\
2011-13\end{array}$ & $\begin{array}{c}36 \text { countries, } \\
2014-15\end{array}$ & $\begin{array}{c}42 \text { countries, } \\
2010-14\end{array}$ \\
\hline
\end{tabular}


Table 2 summarizes the measurements of clientelism, and Table 5 (Appendix) provides descriptive statistics for all measures of the dependent and independent variables.

\section{Empirical strategy}

For the primary tests using V-Dem data, all estimations employ time-series cross-sectional analysis. Fixed-effects estimates are generally the preferred approach for capturing developments within countries over time, where fixed country-level confounding cannot be fully measured by the included covariates. Nevertheless, we also report random effects results for the main V-Dem models in the Appendix (see Table 6), as research on panel data estimation is quite divided about which approach is more appropriate (e.g. Bell and Jones 2015; Clark and Linzer 2015). We assume the relationship between EMB capacity and clientelism is linear, an assumption born out in a correlation plot using the V-Dem data (Figure 2, Appendix). Consequently, all estimations are run with a linear regression.

\section{Control variables}

To leverage the greatest possible sample size for the main analysis we report both a restricted model and an extended model. The restricted model includes three core controls - GDP per capita (logged), GDP growth, and a non-electoral measure of democracy from V-Dem that captures how well countries uphold liberal democratic components like individual freedom and liberties. Consequently, these variables control for economic development and democracy, the usual suspects in the clientelism literature. The restricted model thus controls for the central country-level influences on this relationship while allowing for a maximized sample size.

For the extended model, we include additional controls highlighted in literature, including the degree of party competition, free and fair media, EMB autonomy, population size, ethnic fractionalization, urbanization, and natural resource wealth. Many of these are hypothesized causal mechanisms from the dominant modernization theories about clientelism. Others likely confound the relationship between the EMB capacity and levels of clientelism. These additional controls restrict the sample size considerably, resulting in less coverage and less comparability with the robustness-checks, as many of these cannot be estimated with the sample in the extended model. Therefore, we focus on the restricted model for our main analysis.

\section{Mitigating concerns about endogeneity}


Our empirical strategy seeks to mitigate potential endogeneity bias between EMB capacity and clientelism. As Norris (2019, p. 398) points out, “The institutional arrangements of electoral integrity are not exogenous to levels of electoral integrity or democratization." There is considerable risk that EMB capacity is in part affected by the levels of clientelism. First, clientelism incentivizes embezzlement and corruption that can affect aspects of EMB capacity like staff performance, appointments, and budget. Second, clientelistic systems are informal institutions, with practices that can spread into other areas of public administration, decreasing the EMB's capacity to enforce formal rules. Third, clientelism diverts public resources, which in turn can diminish the resources available to the EMB. Finally, state investments in EMB capacity are likely to depend on pressure from voters and parties, a pressure that in turn can depend on preferences for or against clientelism. Consequently, the causal arrow for any observed negative relationship between EMB capacity and clientelism could go either way.

We employ three strategies to mitigate against the endogeneity problem. First, we use oneand five-year lagged measures of EMB capacity for each estimation. This is a standard technique to ensure the temporal sequence of the relationship works in the theorized direction. Second, we treat endogeneity as omitted variable bias (King et al. 1994). The omitted variable in this case is corruption, as a majority of the above listed sources of endogeneity stem from clientelism's close connection to the informal institution of corruption, and risk of spurring wider corruption that undermines the EMB's capacity. Third, we employ an instrumental variable approach. To be valid, an instrument must be correlated with the endogenous predictor but not directly related to the outcome variable (i.e. any effects on the outcome occur through its mediation of the instrumented predictor) (Sovey and Green 2011). We instrument EMB capacity with the regional average of EMB capacity in that year, excluding the country in question. The regional average of EMB capacity should be a good predictor of the country's EMB capacity due to regional commonalities in institutional settings and trajectories making them likely to influence and follow each other. We verify this first criteria empirically based on the first-stage estimation F-statistic of 81, well above the common rule of thumb of 10 (Staiger and Stock 1997). It is unlikely that average EMB capacity within other countries in the region will have any direct relation to clientelism within a given country (or any unobserved determinants thereof), since this should not affect the actors and contextual factors that determine a country's clientelism. Thus, we argue that the regional average also satisfies the second criteria for an instrumental variable (which cannot be directly observed or tested, Sovey and Green 2011).

To summarize, the empirical strategy aims to assess the relationship between EMB capacity and clientelism for a large spatial and temporal sample and controlling for a host of 
Table 3. Restricted model.

\begin{tabular}{|c|c|c|c|c|c|c|c|c|}
\hline & $\begin{array}{c}\text { (3.1) } \\
\text { Clientelism } \\
\text { Index } \\
\end{array}$ & $\begin{array}{c}\text { (3.2) } \\
\text { Vote buying }\end{array}$ & $\begin{array}{c}\text { (3.3) } \\
\text { Party-voter } \\
\text { linkages } \\
\end{array}$ & $\begin{array}{c}\text { (3.4) } \\
\text { Particularistic } \\
\text { spending }\end{array}$ & $\begin{array}{c}(3.5) \\
\text { Clientelism } \\
\text { Index } \\
\end{array}$ & $\begin{array}{c}\text { (3.6) } \\
\text { Vote buying }\end{array}$ & $\begin{array}{c}(3.7) \\
\text { Party-voter } \\
\text { linkages } \\
\end{array}$ & $\begin{array}{c}\text { (3.8) } \\
\text { Particularistic } \\
\text { spending } \\
\end{array}$ \\
\hline \multirow[t]{2}{*}{ EMB Capacity (Lag1) } & $-0.052^{* * *}$ & $-0.317 * * *$ & $-0.201 * * *$ & $-0.312^{* * *}$ & & & & \\
\hline & $(0.012)$ & $(0.087)$ & $(0.063)$ & $(0.064)$ & & & & \\
\hline \multirow[t]{2}{*}{ EMB Capacity (Lag5) } & & & & & $-0.040 * * *$ & $-0.239 * * *$ & $-0.144 * *$ & $-0.233^{* * *}$ \\
\hline & & & & & $(0.011)$ & $(0.078)$ & $(0.056)$ & $(0.057)$ \\
\hline \multirow[t]{2}{*}{ Liberal component } & -0.089 & 0.687 & $-0.923 * * *$ & $-0.982 * * *$ & $-0.128 * *$ & 0.491 & $-1.114 * * *$ & $-1.243^{* * *}$ \\
\hline & $(0.058)$ & $(0.451)$ & $(0.285)$ & $(0.367)$ & $(0.058)$ & $(0.457)$ & $(0.269)$ & $(0.355)$ \\
\hline \multirow[t]{2}{*}{ GDP per capita Log } & $-0.044 * * *$ & $-0.280 * * *$ & $-0.201 * * *$ & $-0.217 * * *$ & $-0.050^{* * *}$ & $-0.309 * * *$ & $-0.229 * * *$ & $-0.254 * * *$ \\
\hline & $(0.010)$ & $(0.067)$ & $(0.045)$ & $(0.053)$ & $(0.011)$ & $(0.071)$ & $(0.045)$ & $(0.056)$ \\
\hline \multirow[t]{2}{*}{ GDP growth } & $0.031 * * *$ & 0.025 & $0.160 * * *$ & -0.059 & $0.027 * *$ & -0.065 & $0.158^{* * *}$ & -0.058 \\
\hline & $(0.011)$ & $(0.143)$ & $(0.061)$ & $(0.073)$ & $(0.010)$ & $(0.140)$ & $(0.060)$ & $(0.076)$ \\
\hline \multirow[t]{2}{*}{ Constant } & $0.921 * * *$ & $2.237 * * *$ & $2.206^{* * *}$ & $1.612^{* * *}$ & $0.982^{* * *}$ & $2.540 * * *$ & $2.516^{* * *}$ & $2.015^{* * *}$ \\
\hline & $(0.089)$ & $(0.577)$ & $(0.396)$ & $(0.462)$ & $(0.091)$ & $(0.613)$ & $(0.389)$ & $(0.471)$ \\
\hline R2-within & 0.322 & 0.178 & 0.295 & 0.373 & 0.304 & 0.160 & 0.285 & 0.348 \\
\hline R2-between & 0.547 & 0.339 & 0.445 & 0.410 & 0.519 & 0.320 & 0.410 & 0.413 \\
\hline R2-overall & 0.533 & 0.348 & 0.471 & 0.436 & 0.522 & 0.337 & 0.461 & 0.428 \\
\hline Countries & 163 & 161 & 163 & 163 & 163 & 161 & 163 & 163 \\
\hline Observations & 12091 & 3159 & 12091 & 12092 & 11942 & 3114 & 11942 & 11943 \\
\hline
\end{tabular}

Note: All regressions run with robust standard errors and fixed effects. Model 2 and 6 has fewer observations as vote buying is only measured at elections years. ${ }^{*} \mathrm{p}<0.10,{ }^{* *} \mathrm{p}<0.05,{ }^{* * *} \mathrm{p}<0.01$

important variables, while taking steps to avoid measurement bias and endogeneity. For the robustness checks, we draw on eight different measurements of EMB capacity and clientelism that provide the best alternative measurements in terms of validity and sample size. We address concerns about endogeneity using lagged independent variables, controlling for the assumed source of endogeneity as well as employing an instrumental variable approach.

\section{Results}

Table 3 shows the results for the V-Dem clientelism index and its components with the restricted model using both one- and five-year lags on EMB capacity. There is a significant and strong negative relationship between EMB capacity and clientelism. For the one-year lagged EMB capacity in Model 3.1, a one-point increase (on roughly a seven-point scale) decreases clientelism by about 0.052 . In other words, moving from the lowest to highest EMB capacity within this model corresponds to a 0.35 decrease in clientelism, or a third of the total scale. By comparison, the effect size for GDP per capita, a proxy for development and the most commonly cited tool for decreasing clientelism, is more modest. All else equal, doubling GDP per capita yields a decrease of just 0.03 on the clientelism index. When we disaggregate the 
components of clientelism in Models 3.2-3.4, EMB capacity has a corresponding negative effect, although this is somewhat lower for the voter-party linkages component. Looking at Models 3.53.8, we see that while the coefficient for EMB capacity when lagged 5 years is somewhat smaller on all four dependent variables, it is still significant with a strong negative relationship. When estimating the same models using random effects, we see more or less identical results (Table 6, Appendix).

Table 4 provides estimates with the extended model on the same dependent variables with one- and five-year lags of EMB capacity. Note that the liberal component is dropped from these models due to a high degree of collinearity with the measure of free and fair media (access to information and freedom of expression). Furthermore, the sample is considerably smaller $(5,342$ country-years as compared to 12,091 in the restricted model), primarily due to the ethnic fractionalization-measure from CREG starting in 1946 (Nardulli et al. 2012) and the urbanization and population measures stopping at 2000 (Clio-infra 2018; Coppedge et al. 2020b). When looking at the clientelism index, vote buying and particularistic spending for both the one- and five-year lagged models, the results are very similar to and some coefficients even larger than, those in the restricted model (Table 3). However, the party linkages-component drops below standard significance levels for both the one- and five-year lagged models ( $\mathrm{p}$-value is 0.291 for Model 4.3, and 0.835 for Model 4.7). Although the smaller sample size can play a part, it suggests that the supply of this element of clientelism has less to do with EMB capacity. Overall, however, Table 4 shows that the expected relationship between EMB capacity and clientelism is robust to additional controls despite the limited sample. Furthermore, it is noteworthy that some variables that are often highlighted in the clientelism literature show little relationship to clientelism within this model and sample, including urbanization, natural resource wealth, and ethnic fractionalization. ${ }^{7}$

\section{Assessing alternative measures of clientelism and EMB capacity}

In the Appendix, we report estimates using alternative measures of clientelism and EMB capacity, as well as additional tests for endogeneity. Table 11 (Appendix) reports results from ordinal logistic regressions using alternative indicators of vote-buying in the restricted model with a one-year lagged EMB capacity. ${ }^{8}$ Because the IEM has an unbalanced panel, results are

\footnotetext{
7 Although the effect of these variables could be soaked up by the inclusion of GDP per capita in the models. 8 IEM, WVS, and Afrobarometer have four-point or five-point ordinal measures of vote buying, making ordered logistic regression models appropriate. IEM records multiple observations in a given year for some countries because they held more than one election. As panel data regression cannot be estimated with multiple observations within a time unit, we take a "weakest link" aggregation strategy (Goertz and Dixon 2006), meaning that the election
} 
Table 4. Extended model.

\begin{tabular}{|c|c|c|c|c|c|c|c|c|}
\hline & $\begin{array}{l}\text { (4.1) } \\
\text { Clientelism } \\
\text { Index }\end{array}$ & $\begin{array}{c}(4.2) \\
\text { Vote buying }\end{array}$ & $\begin{array}{c}(4.3) \\
\text { Party-voter } \\
\text { linkages }\end{array}$ & $\begin{array}{c}\text { (4.4) } \\
\text { Particularistic } \\
\text { spending }\end{array}$ & $\begin{array}{l}\text { (4.5) } \\
\text { Clientelism } \\
\text { Index }\end{array}$ & $\begin{array}{c}\text { (4.6) } \\
\text { Vote buying }\end{array}$ & $\begin{array}{c}(4.7) \\
\text { Party-voter } \\
\text { linkages }\end{array}$ & $\begin{array}{c}\text { (4.8) } \\
\text { Particularistic } \\
\text { spending }\end{array}$ \\
\hline EMB Capacity (Lag1) & $\begin{array}{c}-0.057^{* * *} \\
(0.015)\end{array}$ & $\begin{array}{c}-0.379 * * * \\
(0.086)\end{array}$ & $\begin{array}{l}-0.102 \\
(0.096)\end{array}$ & $\begin{array}{c}-0.290^{* * *} \\
(0.082)\end{array}$ & & & & \\
\hline EMB Capacity (Lag5) & & & & & $\begin{array}{c}-0.029 * * * \\
(0.009)\end{array}$ & $\begin{array}{c}-0.239 * * * \\
(0.065)\end{array}$ & $\begin{array}{l}-0.011 \\
(0.053)\end{array}$ & $\begin{array}{c}-0.104 * * \\
(0.049)\end{array}$ \\
\hline GDP per capita Log & $\begin{array}{c}-0.044^{* * *} \\
(0.015)\end{array}$ & $\begin{array}{c}-0.230 * * \\
(0.106)\end{array}$ & $\begin{array}{c}-0.302^{* * * *} \\
(0.083)\end{array}$ & $\begin{array}{l}-0.147 \\
(0.090)\end{array}$ & $\begin{array}{c}-0.047 * * * \\
(0.017)\end{array}$ & $\begin{array}{c}-0.235^{* *} \\
(0.108)\end{array}$ & $\begin{array}{c}-0.322^{* * *} \\
(0.087)\end{array}$ & $\begin{array}{c}-0.177^{*} \\
(0.096)\end{array}$ \\
\hline GDP growth & $\begin{array}{l}-0.002 \\
(0.018)\end{array}$ & $\begin{array}{l}-0.038 \\
(0.233)\end{array}$ & $\begin{array}{l}0.013 \\
(0.100)\end{array}$ & $\begin{array}{l}-0.041 \\
(0.132)\end{array}$ & $\begin{array}{l}-0.002 \\
(0.019)\end{array}$ & $\begin{array}{l}-0.049 \\
(0.247)\end{array}$ & $\begin{array}{l}0.009 \\
(0.101)\end{array}$ & $\begin{array}{l}-0.039 \\
(0.136)\end{array}$ \\
\hline Party competition & $\begin{array}{c}-0.025^{*} \\
(0.014)\end{array}$ & $\begin{array}{l}-0.111 \\
(0.099)\end{array}$ & $\begin{array}{l}-0.144^{*} \\
(0.085)\end{array}$ & $\begin{array}{c}-0.238^{* * *} \\
(0.083)\end{array}$ & $\begin{array}{c}-0.036^{* *} \\
(0.015)\end{array}$ & $\begin{array}{l}-0.164 \\
(0.106)\end{array}$ & $\begin{array}{c}-0.171 * \\
(0.090)\end{array}$ & $\begin{array}{c}-0.299 * * * \\
(0.089)\end{array}$ \\
\hline $\begin{array}{l}\text { Access to information } \\
\text { and freedom of } \\
\text { expression }\end{array}$ & $\begin{array}{c}0.015 \\
(0.042)\end{array}$ & $\begin{array}{l}1.239 * * * \\
(0.296)\end{array}$ & $\begin{array}{l}-0.407 \\
(0.288)\end{array}$ & $\begin{array}{l}-0.432 \\
(0.287)\end{array}$ & $\begin{array}{c}0.021 \\
(0.044)\end{array}$ & $\begin{array}{l}1.246^{* * * *} \\
(0.305)\end{array}$ & $\begin{array}{l}-0.406 \\
(0.291)\end{array}$ & $\begin{array}{l}-0.413 \\
(0.307)\end{array}$ \\
\hline EMB autonomy & $\begin{array}{l}-0.012 \\
(0.011)\end{array}$ & $\begin{array}{l}-0.117 \\
(0.077)\end{array}$ & $\begin{array}{c}-0.149 * * \\
(0.071)\end{array}$ & $\begin{array}{l}0.045 \\
(0.071)\end{array}$ & $\begin{array}{c}-0.028^{* * *} \\
(0.011)\end{array}$ & $\begin{array}{c}-0.201 * * * \\
(0.069)\end{array}$ & $\begin{array}{c}-0.187^{* * *} \\
(0.068)\end{array}$ & $\begin{array}{l}-0.047 \\
(0.067)\end{array}$ \\
\hline Population & $\begin{array}{l}0.000 \\
(0.000)\end{array}$ & $\begin{array}{c}0.000 \\
(0.000)\end{array}$ & $\begin{array}{c}0.000 \\
(0.000)\end{array}$ & $\begin{array}{c}0.000^{* *} \\
(0.000)\end{array}$ & $\begin{array}{l}0.000 \\
(0.000)\end{array}$ & $\begin{array}{l}0.000 \\
(0.000)\end{array}$ & $\begin{array}{l}0.000 \\
(0.000)\end{array}$ & $\begin{array}{l}0.000 \\
(0.000)\end{array}$ \\
\hline Urbanization & $\begin{array}{c}0.025 \\
(0.100)\end{array}$ & $\begin{array}{c}0.410 \\
(0.850)\end{array}$ & $\begin{array}{c}0.719 \\
(0.526)\end{array}$ & $\begin{array}{l}0.239 \\
(0.597)\end{array}$ & $\begin{array}{l}0.045 \\
(0.104)\end{array}$ & $\begin{array}{c}0.473 \\
(0.879)\end{array}$ & $\begin{array}{l}0.769 \\
(0.520)\end{array}$ & $\begin{array}{c}0.353 \\
(0.618)\end{array}$ \\
\hline $\begin{array}{l}\text { Natural resource } \\
\text { production per capita }\end{array}$ & $\begin{array}{c}0.000^{* *} \\
(0.000)\end{array}$ & $\begin{array}{l}-0.000 \\
(0.000)\end{array}$ & $\begin{array}{l}0.000^{*} \\
(0.000)\end{array}$ & $\begin{array}{l}-0.000 \\
(0.000)\end{array}$ & $\begin{array}{l}0.000^{* *} \\
(0.000)\end{array}$ & $\begin{array}{l}-0.000 \\
(0.000)\end{array}$ & $\begin{array}{l}0.000^{*} \\
(0.000)\end{array}$ & $\begin{array}{l}-0.000 \\
(0.000)\end{array}$ \\
\hline Ethnic fractionalization & $\begin{array}{l}-0.289 \\
(0.189)\end{array}$ & $\begin{array}{l}-0.945 \\
(0.837)\end{array}$ & $\begin{array}{l}-1.493 \\
(1.025)\end{array}$ & $\begin{array}{l}-0.445 \\
(1.117)\end{array}$ & $\begin{array}{l}-0.321 \\
(0.204)\end{array}$ & $\begin{array}{l}-1.173 \\
(0.840)\end{array}$ & $\begin{array}{l}-1.585 \\
(1.062)\end{array}$ & $\begin{array}{l}-0.648 \\
(1.222)\end{array}$ \\
\hline Constant & $\begin{array}{c}0.957^{* * *} \\
(0.120)\end{array}$ & $\begin{array}{c}1.697 * * \\
(0.718)\end{array}$ & $\begin{array}{c}3.164^{* * *} \\
(0.634)\end{array}$ & $\begin{array}{c}0.753 \\
(0.750)\end{array}$ & $\begin{array}{c}0.990^{* * *} \\
(0.133)\end{array}$ & $\begin{array}{l}1.809 * * \\
(0.760)\end{array}$ & $\begin{array}{c}3.352^{* * *} \\
(0.662)\end{array}$ & $\begin{array}{r}1.040 \\
(0.805)\end{array}$ \\
\hline R2-within & 0.269 & 0.229 & 0.275 & 0.218 & 0.229 & 0.190 & 0.268 & 0.181 \\
\hline R2-between & 0.369 & 0.392 & 0.285 & 0.343 & 0.295 & 0.318 & 0.232 & 0.337 \\
\hline R2-overall & 0.385 & 0.388 & 0.333 & 0.362 & 0.308 & 0.319 & 0.287 & 0.333 \\
\hline Countries & 131 & 121 & 131 & 131 & 131 & 121 & 131 & 131 \\
\hline Observations & 5342 & 1376 & 5342 & 5342 & 5334 & 1374 & 5334 & 5334 \\
\hline
\end{tabular}

Note: All regressions run with robust standard errors and fixed effects. Liberal component not included in the models as it is too highly correlated to freedom of expression and alternative sources of information. Model 2 and 6 has fewer observations as vote buying is only measured at elections years. ${ }^{*} \mathrm{p}<0.10,{ }^{* *} \mathrm{p}<0.05,{ }^{* * *} \mathrm{p}<0.01$

reported for both TSCS random effects estimation and pooled OLS, to show that the results are robust to the latter, more parsimonious estimation (Gelman 2007, pp. 175-77). Both Model 11.1 and 11.2 suggest that EMB capacity has a significant and strong negative relationship with vote buying. However, for the three citizen survey measures, the estimated coefficient for EMB capacity is non-significant ( $\mathrm{p}$-value is 0.224 for Model 11.3, 0.318 for Model 11.4 and 0.114 for Model 11.5).

To some extent, the divergent findings in Table 11 may come down to a question of who is better-suited to evaluate country-level trends in vote buying: experts, electoral observers, or

with the highest reported vote buying in IEM is used. This makes for a more conservative estimation, by taking the "worst" election of each year. The WVS and Afrobarometer are estimated with multilevel models that cluster the individual responses at the country-level. 
citizens themselves. These results thus offer an avenue for future research, adding to discussions about whether expert opinions are more accurate than mass surveys. If citizens are just as good at assessing clientelism as experts, it is potentially problematic that neither measure directly assessing citizens perceptions about vote buying shows a significant relationship to EMB capacity. However, in terms of coverage and measurement proximity, it could also be argued that IEM provides a better measure, and it thus offers important support for the V-Dem findings.

Table 12 (Appendix) provides results for the alternative indicators of EMB capacity. ${ }^{9}$ With the PEI, there is a significant and strong negative relationship. A one point-increase in electoral management procedures (on a 10-point scale) is associated with a 0.06 decrease in clientelism. Considering that this variable spans from about 1.8 to 9.8, moving from least to most amounts to a decrease in clientelism of about half the scale. Similarly, the QED-data shows a significant, negative relationship betweeb pre-election administrative capacity and clientelism, but no significant relationship for election-day administrative capacity. This further supports the V-Dem results, and in addition, suggests that certain aspects of EMB capacity may matter more than others. However, when EMB capacity is estimated through website analysis using Garnett (2019), there is no significant observed relationship with clientelism. This null effect could be the result of selection bias in a small (92 countries) sample for only one year.

When looking at the results from these robustness checks, it is noteworthy that V-Dem, IEM, PEI and QED are all measured based on either direct expert assessments or coding of reports written by experts on a certain election. By contrast, data from the Afrobarometer, WVS, and Garnett - datasets that do not produce supporting evidence - come from non-expert sources like mass surveys or factual coding by researchers. This suggests that different datagenerating methods produce different results for the observed relationship between EMB capacity and clientelism. Furthermore, these robustness checks indicate that EMB capacity may exhibit a weaker relationship with some varieties of clientelism. Finally, the three datasets that do not provide supporting evidence are also more restrictive in sample or have some questionable concept-measurement validity. Thus, the results of this empirical investigation suggest that the observed negative association between EMB capacity and supplies of clientelism using V-Dem data is unlikely to stem from measurement bias.

\footnotetext{
${ }^{9}$ Like IEM, QED records multiple observations for some country-years, and weakest link" aggregation (Goertz and Dixon 2006), i.e. taking the elections with the lowest reported EMB capacity, is used. The PEI and Garnett-data have singular scores for each country and are therefore analyzed with pooled OLS estimations.
} 
To address endogeneity beyond using lagged independent variables, Table 13 (Appendix) shows the results when treating the endogeneity as an omitted variable bias. For Models 13.1-13.4 using the V-Dem measure of corruption, the estimated relationship of one- and five-year lags of EMBcapacity is robust to including corruption, and the coefficient is very similar to the main models. While only the one-year lag has a significant (negative) coefficient when controlling for corruption using the WGI measure, this measure is only marginally significant and the model employs more restricted sample. Therefore, it is difficult to determine whether the drop in significance occurs due to a reduction of endogeneity bias (by including an important omitted variable) or if this null result is really driven by sample bias.

An instrumental variable estimation further confirms that endogeneity is not driving the relationship between EMB capacity and clientelism. Table 14 (Appendix) shows that using the regional average of EMB capacity as an instrument for EMB capacity, there is a yet again significant and strong negative association (coefficient $=-0.063) .{ }^{10}$ Consequently, employing lagged dependent variables, treating endogeneity as an omitted variable bias, and an instrumental variable approach largely support to the theorized relationship between EMB capacity and the supply of clientelism.

\section{Additional Robustness checks}

As a consequence of the varied nature of clientelism, however, there could be important temporal and spatial heterogeneity disguised in this full sample. Therefore, we estimate split samples for six world regions ${ }^{11}$ and two separate time periods: 1946-2016 and 1974-2016. These two periods signify the start of two trends in regime-changes, the end of WWII and the beginning of the third wave of democracy (Huntington 1991). Table 7 (Appendix) shows the results for a one-year lagged EMB capacity using split samples for each of six world regions, along with the full sample for comparison. The results suggest that EMB capacity has the largest influence on clientelism in two regions: Western Europe/North America and Eastern Europe/Central Asia. However, estimates in Table 8 (Appendix) show that there is still a significant, negative relationship, albeit smaller (coefficient is -0.033 as compared to -0.052 in the

\footnotetext{
${ }_{10}$ We also employed two additional instrumental variables that yielded negative but not statistically significant results. These results, and a discussion why we find them less appropriate than the instrumental variable discussed in the article, can be found in the appendix.

${ }^{11}$ Eastern Europe and Central Asia, Latin America and the Caribbean, Sub-Saharan Africa, Middle East and North Africa, Western Europe and North America, Asia and Pacific.
} 
full sample) of one-year lagged EMB capacity when excluding these regions. Consequently, the relationship between EMB capacity and the supply of clientelism is not driven by any regional outliers, even if it is particularly pronounced for Western Europe/North America and Eastern Europe/Central Asia. Table 9 (Appendix), in turn shows the results for 1946-2016 and 19742016 using one- and five-year lags of EMB capacity, and we see that the relationship remains significant and the coefficients only somewhat smaller within these samples.

It also is possible that EMB capacity, rather than having an independent effect, acts as a proxy for a more general administrative capacity. Therefore, we run estimations that include Hanson and Sigman's (2013) measure of state capacity and the WGI measure of government effectiveness (Kaufman and Kraay 2016) to assess if the hypothesized effect of EMB capacity is robust to, and thus independent of, these larger aspects of state administrative capacity. Figure 3 and 4 (Appendix) show correlation plots between EMB capacity and state capacity and WGI government effectiveness, respectively. Both plots show that the variables are indeed related, but that it is possible to have high levels of one and low levels of the other.

Table 10 (Appendix) presents the results when including these measures of state capacity, using both the restricted and extended model for Hanson and Sigman's (2013) measure (Models 10.1-10.4), but only the restricted model for the WGI measure (Models 10.5-10.6) as the extended model renders too few observations. The findings with one- and five-year lags of EMB capacity remain robust when including state capacity as an additional covariate; the coefficient size is almost the same as the restricted and extended model without state capacity. In Model 10.5, we see that EMB capacity lagged one year has a somewhat smaller, but still large and significant negative effect on the clientelism index when including government effectiveness. However, the five-year lagged EMB capacity is not significantly related clientelism when including the WGI measure. Thus, while the estimates show some variation when controlling for overall state capacity, the results generally continue to support a negative relationship between EMB capacity and the supply of clientelism.

\section{Conclusions}

Until now, economic development has dominated our understanding of the detriments of clientelism, resulting in limited scholarly attention to how institutions of electoral management affect clientelistic behavior. This article takes a first step at integrating the proximate, but until now separate, research fields of clientelism and electoral integrity. We argue that EMB capacity deters clientelism through two mechanisms. First, it increases trust in elections, increasing the 
costs for voters who engage in clientelism rather than voicing their genuine preferences. Second, increases in EMB capacity undermine broker monitoring capacity, which increases voter moral hazard and the costs of hiring brokers, leading to higher party costs of engaging in clientelism. As such, we theorize that improvements in EMB capacity should be associated with declines in the supply of clientelism, all else equal.

This theory is tested using V-Dem data covering over 160 countries from 1900-2016. A strong, negative relationship is observed when using both a restricted and extended set of controls and for temporal and regional subsamples Using several alternative measures of EMB capacity and clientelism to assess concerns of measurement bias, the variables with highest concept-measurement validity and country-year coverage support the findings in the V-Dem analysis. However, the measures with more restrictive samples or questionable validity report no significant effect, leaving questions about whether only certain aspects of EMB capacity and clientelism are related to each other. The relationship also largely holds when using one- and five-year lags, including corruption as a control, as well as using the regional average of EMB capacity as an instrumental variable, suggesting that the results are not driven by endogeneity. While the relationship is most pronounced in two out of six world regions, there is still a strong negative association between EMB capacity and clientelism when excluding these regions. Furthermore, the relationship is generally robust to controlling for state capacity and government effectiveness, suggesting that effects of the EMB are independent of overall state capacity.

From this, we conclude that increases to EMB capacity have a negative effect on clientelism within countries. This finding bridges the literature on clientelism and electoral integrity, suggesting that scholars in these fields may provide valuable lessons for each other. Our results complement the dominant focus on economic development in the clientelism literature, taking a step toward a more encompassing understanding by highlighting how formal institutions and their performance matter in this process. Lastly, our work provides practical empirical insights. For donors concerned about clientelism and electoral integrity, prioritizing investments in capacity building programs for electoral management bodies may provide fruitful dividends.

Looking ahead, this article illuminates several promising areas for future research. We provide a quantitative, within-country overview of the relationship. Assessments at the microlevel would help uncover to what extent the relationship actually depends on the presumed causal chain or some other mechanisms. Furthermore, future work could address what elements of EMB capacity affect what components of clientelism, so as to understand when and why we should expect this relationship to exist. Such research will help us understand some of the null 
results in the robustness checks in this article and help policymakers decide which types of capacity building programs to prioritize and in which settings. Finally, a further integration of the literatures on electoral integrity and clientelism would greatly improve our understanding of how electoral management and electoral institutions affect clientelism, and vice versa. As much time and money goes into putting lessons from these studies into practice by donors and nongovernmental organizations, such research could bolster efforts to achieve important development and governance goals.

\section{References}

Acemoglu, Daron and James A. Robinson. 2010. "The role of institutions in growth and development." Review of Economics and Institutions 1(2): Article 1.

Acemoglu, Daron and James A. Robinson. 2012. Why nations fail the origins of power, prosperity and poverty. London: Profile.

Adcock, Robert and David Collier. 2001. "Measurement Validity: A Shared Standard for Qualitative and Quantitative Research." American Political Science Review 95(3): 529-546.

Afrobarometer. 2013. Round 5 (2011-2013). URL: http://afrobarometer.org/data/mergedround-5-data-34-countries-2011-2013-last-update-july-2015

Afrobarometer. 2015. Round 6 (2014-2015). URL: http://afrobarometer.org/data/mergedround-6-data-36-countries-2016

Aspinall, Edward. 2014. "When Brokers Betray: Clientelism, Social Networks, and Electoral Politics in Indonesia." Critical Asian Studies 46(4): 545-570.

Aspinall, Edward and Allen Hicken. 2020. "Guns for hire and enduring machines: Clientelism beyond parties in Indonesia and the Philippines.” Democratization 27(1): 137-156.

Baldwin, Kate and John D. Huber. 2010. "Economic versus cultural differences: Forms of ethnic diversity and public goods provision.” American Political Science Review 104(4): 644-662.

Bell, Andrew and Kelvyn Jones. 2015. "Explaining Fixed Effects: Random Effects Modeling of Time-Series Cross-Sectional and Panel Data." Political Science Research and Methods 3(1): 133-153.

Berenschot, Ward and Edward Aspinall. 2020. "How clientelism varies: Comparing patronage democracies." Democratization 27(1): 1-19.

Birch, Sarah. 2008. "Electoral Institutions and Popular Confidence in Electoral Processes: A cross-national analysis." Electoral Studies 27(2): 305-320.

Birch, Sarah. 2011. Electoral Malpractice. Oxford University Press.

Bowler, Shaun, Thomas Brunell, Todd Donovan and Paul Gronke. 2015. "Election Administration and Perceptions of Fair Elections.” Electoral Studies 38(June): 1-9. 
Brownlee, Jason. 2009. "Harbinger of democracy: competitive elections before the end of authoritarianism." In Democratization by elections: A new mode of transition, ed. Staffan Lindberg. Baltimore: Johns Hopkins University Press.

Bustikova, Lenka and Cristina Corduneanu-Huci, C. 2017. "Patronage, Trust, and State Capacity." World Politics 69(2): 277-326.

Calvo, Ernesto and Maria Victoria Murillo. (2004). "Who Delivers? Partisan Clients in the Argentine Electoral Market.” American Journal of Political Science 48(4): 742-757.

Catt, Helena, Andrew Ellis, Michael Maley, Alan Wall and Peter Wolf. 2014. Electoral Management Design: Revised Edition. Stockholm: International IDEA.

Chandra, Kanchan. 2007. "Counting heads: a theory of voter and elite behaviour in patronage democracies." In Patrons, clients, and policies: Patterns of democratic accountability and political competition, ed. Herbert Kitschelt and Steven Wilkinson. Cambridge: Cambridge University Press.

Charron, Nicolas. 2016. "Do corruption measures have a perception problem? Assessing the relationship between experiences and perceptions of corruption among citizens and experts." European Political Science Review 8(1): 147-171.

Chubb, Judith. 1982. Patronage, power, and poverty in southern Italy: A tale of two cities. Cambridge: Cambridge University Press.

Clark, Alistair. 2019. "The cost of democracy: The determinants of spending on the public administration of elections." International Political Science Review 40(3): 354-369.

Clark, Tom and Drew Linzer. 2015. "Should I Use Fixed or Random Effects?” Political Science Research and Methods 3(2): 399-408.

Clio-Infra. (2018). Clio-Infra Project (Database). URL: http://www.clio-infra.eu/

Cohn, Nate, Josh Katz, Denise Lu, Charlie Smart, Ben Smithgall and Andrew Fischer. 2020. Iowa Caucus Results Riddled With Errors and Inconsistencies. New York Times. URL: https://www.nytimes.com/2020/02/06/upshot/iowa-caucuses-errors-results.html

Coppedge, Michael, John Gerring, Carl Henrik Knutsen, Staffan I. Lindberg, Jan Teorell, David Altman, Michael Bernhard, M. Steven Fish, Adam Glynn, Allen Hicken, Anna Luhrmann, Kyle L. Marquardt, Kelly McMann, Pamela Paxton, Daniel Pemstein, Brigitte Seim, Rachel Sigman, Svend-Erik Skaaning, Jeffrey Staton, Steven Wilson, Agnes Cornell, Nazifa Alizada, Lisa Gastaldi, Haakon Gjerløw, Garry Hindle, Nina Ilchenko, Laura Maxwell, Valeriya Mechkova, Juraj Medzihorsky, Johannes von Römer, Aksel Sundström, Eitan Tzelgov, Yi-ting Wang, Tore Wig and Daniel Ziblatt. (2020a). "V-Dem Country-Year Dataset v10". Varieties of Democracy (V-Dem) Project. https://doi.org/10.23696/vdemds20.

Coppedge, Michael, John Gerring, Carl Henrik Knutsen, Staffan I. Lindberg, Jan Teorell, David Altman, Michael Bernhard, M. Steven Fish, Adam Glynn, Allen Hicken, Anna Luhrmann, Kyle L. Marquardt, Kelly McMann, Pamela Paxton, Daniel Pemstein, Brigitte Seim, Rachel Sigman, Svend-Erik Skaaning, Jeffrey Staton, Agnes Cornell, Lisa Gastaldi, Haakon Gjer- løw, Valeriya Mechkova, Johannes von Römer, Aksel Sundtröm, Eitan Tzelgov, Luca Uberti, Yi-ting Wang, Tore Wig and Daniel Ziblatt. (2020b). "V-Dem Codebook v10" Varieties of Democracy (VDem) Project. 
Dahl, Robert. 1971. Polyarchy: Participation and Opposition. New Haven: Yale University Press.

Denissen, Ingeborg. 2020. "How democratization benefits brokers: A comparison of Mexico City and Khartoum." Democratization 27(1): 44-60.

Dixit, Avinash and John Londregan. 1996. "The Determinants of Success of Special Interests in Redistributive Politics.” The Journal of Politics 58(4): 1132-1155.

Driscoll, Barry. 2018. "Why Political Competition Can Increase Patronage." Studies in Comparative International Development 53(4): 404-427.

Driscoll, Barry. 2020. "Democratization, party systems, and the endogenous roots of Ghanaian clientelism.” Democratization 27(1): 119-136.

Easterly, William and Ross Levine. 1997. "Africa's growth tragedy policies and ethnic divisions." The Quarterly Journal of Economics 112(4): 1203-1250.

Edgell, Amanda B., Valeriya Mechkova, David Altman, Michael Bernhard, Staffan I. Lindberg. 2018. "When and where do elections matter? A global test of the democratization by elections hypothesis, 1900-2010." Democratization 25(3): 422-444.

Elklit, Jørgen and Andrew Reynolds. 2002. "The Impact of Election Administration on the Legitimacy of Emerging Democracies: A New Comparative Politics Research Agenda." Commonwealth \& Comparative Politics 40(2): 86-119.

Elklit, Jørgen and Andrew Reynolds. 2005. "Judging elections and election management quality by process.” Representation 41(3): 189-207.

Fukuyama, Francis. 2013. "Democracy and the quality of the state." Journal of Democracy 24(4): 516.

Gans-Morse, Jordan, Sebastián Mazzuca and Simeon Nichter. 2014. "Varieties of Clientelism: Machine Politics during Elections." American Journal of Political Science 58(2): 415-432.

Garnett, Holly Ann. 2019. "Evaluating electoral management body capacity." International Political Science Review 40(3): 335-353.

Gelman, Andrew. 2007. Data analysis using regression and multilevel/ hierarcbical models. Cambridge: Cambridge University Press.

Goertz Gary and W.F. Dixon. 2006. "Substitutability, aggregation, and weakest-link measures." In Social Science Concepts: A User's Guide, ed. Gary Goertz, 129-155. Princeton, NJ: Princeton University Press.

Hanson, Jonathan K. and Rachel Sigman. 2013. "Leviathan's Latent Dimensions: Measuring State Capacity for Comparative Political Research.” APSA 2011 Annual Meeting Paper. Available at SSRN:

https://ssrn.com/abstract $=1899933$

Hartlyn, Jonathan, Jennifer Mccoy and Thomas M. Mustillo. 2008. "Electoral Governance Matters: Explaining the Quality of Elections in Contemporary Latin America." Comparative Political Studies 41(1): 73-98. 
Helmke, Gretchen and Steven Levitsky. 2004. "Informal Institutions and Comparative Politics: A Research Agenda." Perspectives on Politics 2(4): 725-740.

Hicken, Allen. 2011. “Clientelism.” Annual Review of Political Science 14(1): 289-310.

Huntington, Samuel. 1991. The third wave: Democratization in the late twentieth century (Julian J. Rothbaum distinguished lecture series, 4).

Inglehart, R., C. Haerpfer, A. Moreno, C. Welzel, K. Kizilova, J. Diez-Medrano, M. Lagos, P. Norris, E. Ponarin \& B. Puranen et al. (eds.). 2014. World Values Survey: Round Six - CountryPooled Datafile.Version: www.worldvaluessurvey.org/WVSDocumentationWV6.jsp. Madrid: JD Systems Institute.

Isaksson, Ann-Sofie and Arne Bigsten. 2017. "Clientelism and ethnic divisions in African countries.” African Affairs 116(465): 621-647.

James, Toby S. 2019. "Better workers, better elections? Electoral management body workforces and electoral integrity worldwide.” International Political Science Review 40(3): 370-390.

James, Toby S., Holly Ann Garnett, Leontine Loeber and Carolien Van Ham. 2019. "Electoral management and the organisational determinants of electoral integrity: Introduction." International Political Science Review 40(3): 295-312.

Karp, Jeffrey, Alessandro Nai, Miguel Angel Lara Otaola and Pippa Norris. 2017. Building Professional Electoral Management. Sydney: Sydney University, Electoral Integrity Project.

Kaufmann, Daniel and Art Kraay. 2016. "Worldwide Governance Indicators.” URL: http:/ / www.govindicators.org

Keefer, Philip. 2007. "Clientelism, Credibility, and the Policy Choices of Young Democracies." American Journal of Political Science 51(4): 804-821.

Keefer, Philip and Razvan Vlaicu. 2008. "Democracy, credibility, and clientelism." Journal of Law, Economics, and Organization 24(2): 371-406.

Kelley, Judith G. 2012. Monitoring democracy: When international election observation works, and why it often fails. Princeton, N.J.: Princeton University Press.

Kerr, Nicholas N. 2014. "EMB Performance and Perceptions of Electoral Integrity in Africa." In Advancing Electoral Integrity, ed. Pippa Norris, Richard W. Frank and Ferran Martinez I Coma, Chapter 10. Oxford: Oxford University Press.

Kerr, Nicholas N. 2018. "Election-Day Experiences and Evaluations of Electoral Integrity in Unconsolidated Democracies: Evidence from Nigeria.” Political Studies 66(3): 667-686.

Kerr, Nicholas N. and Anna Lührmann. 2017. "Public trust in manipulated elections: The role of election administration and media freedom." Electoral Studies 50(December): 50-67.

King, Gary, Robert O. Keohane and Sidney Verba. 1994. Designing social inquiry: Scientific inference in qualitative research. Princeton, N.J.: Princeton University Press. 
Kitschelt, Herbert and Steven Wilkinson. 2007. “Citizen-politician linkages: an introduction.” In Patrons, clients, and policies: Patterns of democratic accountability and political competition, ed. Kitschelt, Herbert and Steven Wilkinson. Cambridge: Cambridge University Press.

Kitschelt, Herbert and Daniel Kselman. 2013. "Economic Development, Democratic Experience, and Political Parties' Linkage Strategies." Comparative Political Studies 46(11): 14531484.

Lemarchand, Rene and Keith Legg. 1972. "Political Clientelism and Development: A Preliminary Analysis." Comparative Politics 4(2): 149-178.

Lijphart, Arend. 2012. Patterns of democracy government forms and performance in thirty-six countries (2nd ed.). New Haven: Yale University Press.

Lindberg, Staffan I. 2009a. "Introduction. Democratization by Elections: A New Mode of Transitions." In Democratization by elections: A new mode of transition, ed. Staffan I. Lindberg. Baltimore: Johns Hopkins University Press.

Lindberg, Staffan I. 2009b. "A theory of elections as a mode of transition." In Democratization by elections: A new mode of transition, ed. Staffan I. Lindberg. Baltimore: Johns Hopkins University Press.

Lindberg, Staffan I. 2010. "What accountability pressures do MPs in Africa face and how do they respond? Evidence from Ghana.” The Journal of Modern African Studies 48(1): 117-142.

Lindberg, Staffan I. 2013. "Have the cake and eat it: The rational voter in Africa." Party Politics 19(6): 945-961.

Magaloni, Beatriz, Alberg Diaz-Cayeros and Federico Estévez. 2007. "Clientelism and portfolio diversification: a model of electoral investment with applications to Mexico." In Patrons, clients, and policies: Patterns of democratic accountability and political competition, ed. Herbert Kitschelt and Steven Wilkinson. Cambridge: Cambridge University Press.

Mares, Isabela and Lauren Young. 2016. "Buying, Expropriating, and Stealing Votes." Annual Review of Political Science 19: 267.

McNamara, Audrey. 2020. "Confusion and Embarrassment in Iowa: What Went Wrong, and What Happens Next?” CBS News. URL:

https://www.cbsnews.com/news/iowa-caucus-results-errors-delays-what-happened-confusionembarrassment/

Medina, Luis Fernando and Susan Stokes. 2007. "Monopoly and monitoring: an approach to political clientelism." In Patrons, clients, and policies: Patterns of democratic accountability and political competition, ed. Herbert Kitschelt and Steven Wilkinson. Cambridge: Cambridge University Press.

Miller, Gary and Thomas Hammond. 1994. "Why Politics is More Fundamental Than Economics: Incentive-Compatible Mechanisms Are Not Credible.” Journal of Theoretical Politics 6(1): 5-26.

Mozaffar, Shaheen. 2002. "Patterns of Electoral Governance in Africa's Emerging Democracies.” International Political Science Review 23(1): 85-101. 
Mozaffar, Shaheen and Andreas Schedler. 2002. "The Comparative Study of Electoral Governance-Introduction.” International Political Science Review 23(1): 5-27.

Nardulli, Peter F., Cara J. Wong, Ajay Singh, Buddy Peyton, and Joseph Bajjaliegh. 2012. "The Composition of Religious and Ethnic Groups (CREG) Project." Cline Center for Democracy, University of Illinois, Urbana-Champaign.

http://www.clinecenter.illinois.edu/publications/CREG-White_Paper.pdf.

Nichter, Simeon. 2008. "Vote Buying or Turnout Buying? Machine Politics and the Secret Ballot." American Political Science Review 102(1): 19-31.

Nichter, Simeon. 2011. "Electoral Clientelism or Relational Clientelism? Healthcare and Sterilization in Brazil." Paper presented at Annual Meeting of the American Political Science Association.

Norris, Pippa. 2004. Electoral Engineering: Voting Rules and Political Behavior. Cambridge: Cambridge University Press.

Norris, Pippa. 2009. "All elections are not the same: why power-sharing elections strengthen democratization." In Democratization by elections: A new mode of transition, ed. Staffan I. Lindberg. Baltimore: Johns Hopkins University Press.

Norris, Pippa. 2015. Why elections fail. Cambridge: Cambridge University Press.

Norris, Pippa. 2019. "Conclusions: The new research agenda on electoral management." International Political Science Review 40(3): 391-403.

Norris, Pippa and Max Grömping. 2019. Perceptions of Electoral Integrity, (PEI-7.0). URL: https://doi.org/10.7910/DVN/PDYRWL

North, Douglas. 1991. "Institutions.” Journal of Economic Perspectives 5(1): 97-112.

Pemstein, Daniel, Kyle L. Marquardt, Eitan Tzelgov, Yi-ting Wang, Juraj Medzihorsky, Joshua Krusell, Farhad Miri, and Johannes von Römer. (2020). "The V-Dem Measurement Model: Latent Variable Analysis for Cross-National and Cross-Temporal Expert-Coded Data". V-Dem Working Paper No. 21. 5th edition. University of Gothenburg: Varieties of Democracy Institute.

Posner, Daniel N. 2005. Institutions and Ethnic Politics in Africa. New York: Cambridge University Press.

Robinson, James A. and Thierry Verdier. 2013. “The Political Economy of Clientelism.” Scandinavian Journal of Economics 115(2): 260-291.

Rothstein, Bo. 2011. The quality of government corruption, social trust, and inequality in international perspective. Chicago, Ill.: University of Chicago Press.

Rothstein, Bo. 2018. "Fighting Systemic Corruption: The Indirect Strategy." Daedalus 147(3): 3549.

Ruiz-Rufino, Rubén, Sarah Birch, Ursula Daxecker and Kristine Höglund. 2020. "The Effect of Alternation in Power on Electoral Intimidation in Democratizing Regimes." Journal of Peace Research 57(1): 126-39. 
Schedler, Andreas. 2002. "The menu of manipulation. (Elections without democracy)". Journal of Democracy 13(2): 36-50.

Schedler, Andreas. 2009a. "The contingent power of authoritarian elections." In Democratization by elections: A new mode of transition, ed. Staffan I. Lindberg. Baltimore: Johns Hopkins University Press.

Schedler, Andreas. 2009b. "Sources of competition under electoral authoritarianism." In Democratization by elections: A new mode of transition, ed. Staffan I. Lindberg. Baltimore: Johns Hopkins University Press.

Seitz, Amanda and David Klepper. 2020. "Online Conspiracy Theories Flourish after Iowa Caucus Fiasco.” Associated Press. URL: https://apnews.com/8ae0e5172130f81265172fbd3e65094a

Shefter, Mozaffar. 1994. Political parties and the state: The American historical experience. Princeton N.J: Princeton University Press.

Sigman, Rachel and Staffan I. Lindberg. 2017. "Neopatrimonialism and Democracy: An Empirical Investigation of Africa's Political Regime.” V-Dem Working Paper Series 2017:56.

Sovey, Allison J., and Donald P. Green. 2011. "Instrumental Variables Estimation in Political Science: A Readers' Guide." American Journal of Political Science 55(1): 188-200.

Staiger, Douglas and James H. Stock. 1997. "Instrumental variables regression with weak instruments." Econometrica 65(3): 557-586.

Stokes, Susan. 2005. "Perverse accountability: A formal model of machine politics with evidence from argentina." American Political Science Review 99(3): 315-325.

Stokes, Susan. 2011. "Political Clientelism." In The Oxford Handbook of Political Science, ed. Robert E. Goodin. Oxford: Oxford University Press.

Stokes, Susan, Thad Dunning, Marcelo Nazareno and Valeria Brusco. 2013. Brokers, voters, and clientelism: The puzzle of distributive politics. Cambridge: Cambridge University Press.

van de Walle, Nicolas. 2007. 'The Path from Neopatrimonialism: Democracy and Clientelism in Africa Today.' Working Paper:

https://ecommons.cornell.edu/bitstream/handle/1813/55028/2007 WP3 vandeWalle.pdf?seq uence $=1$ \&is Allowed $=\mathrm{y}$

Van Ham, Carolien and Holly Ann Garnett. 2019. "Building impartial electoral management? Institutional design, independence and electoral integrity." International Political Science Review 40: 313-334.

Van Ham, Carolien and Staffan I. Lindberg. 2015a. "Vote Buying Is A Good Sign: Alternate Tactics of Fraud in Africa 1986-2012.” V-Dem Working Paper Series 2015:3.

Van Ham, Carolien and Staffan I. Lindberg. 2015b. "When Guardians Matter Most: Exploring the Conditions Under Which Electoral Management Body Institutional Design Affects Election Integrity." Irish Political Studies 30(4): 454-481. 
Veenendaal, Wouter and Jack Corbett. 2020. "Clientelism in small states: How smallness influences patron-client networks in the Caribbean and the Pacific.” Democratization 27(1): 61-80.

Vicente, Pedro C. and Leonard Wantchekon. 2009. "Clientelism and vote buying: lessons from field experiments in African elections." Oxford Review of Economic Policy 25(2): 292-305,

Weghorst, Keith and Staffan I Lindberg. 2011. "Effective Opposition Strategies: Collective Goods or Clientelism?” Democratization 18(5): 1193-1214.

Weghorst, Keith and Staffan I. Lindberg. 2013. "What Drives the Swing Voter in Africa?" American Journal of Political Science 57(3): 717-734.

Weiss, Meredith L. 2020. "Duelling networks: Relational clientelism in electoral-authoritarian Malaysia.” Democratization 27(1): 100-118.

Yıldırım, Kerem. 2020. "Clientelism and dominant incumbent parties: Party competition in an urban Turkish neighbourhood." Democratization 27(1): 81-99.

Yildırım, Kerem and Herbert Kitschelt. 2020. "Analytical perspectives on varieties of clientelism." Democratization 27(1): 20-43. 


\section{Appendix}

Table 3. Descriptive Statistics

\begin{tabular}{|c|c|c|c|c|c|}
\hline Variable & $\mathbf{N}$ & Mean & SD & Min & Max \\
\hline \multicolumn{6}{|l|}{ EMB Capacity } \\
\hline V-Dem EMB Capacity & 12124 & 0.2101 & 1.5270 & -3.109 & 3.131 \\
\hline PEI Electoral Procedures & 750 & 6.7815 & 1.8976 & 1.875 & 9.7941 \\
\hline QED Pre Election Capacity & 858 & 3.8531 & 0.4776 & 1 & 4 \\
\hline QED Election Day Capacity & 844 & 3.7026 & 0.6752 & 1 & 4 \\
\hline Garnett EMB Capacity & 92 & 2.2636 & 0.6953 & .33 & 3 \\
\hline \multicolumn{6}{|l|}{ Clientelism } \\
\hline V-Dem Clientelism Index & 12124 & 0.4951 & 0.2701 & .013 & .985 \\
\hline V-Dem Vote Buying & 3177 & 0.0929 & 1.4105 & -3.067 & 3.184 \\
\hline V-Dem Voter-Party Linkages & 12124 & 0.0174 & 1.4528 & -3.267 & 3.365 \\
\hline V-Dem Particularistic Spending & 12125 & -0.7676 & 1.3093 & -3.711 & 3.035 \\
\hline Afrobarometer Vote Buying Experience & 50536 & 0.2746 & 0.7069 & 0 & 3 \\
\hline Afrobarometer Vote Buying Perceptions & 49017 & 1.4685 & 1.0866 & 0 & 3 \\
\hline WVS Vote Buying Perceptions & 51120 & 2.4881 & 1.0713 & 1 & 4 \\
\hline IEM Vote Buying & 149 & 1.4966 & 0.8670 & 1 & 5 \\
\hline
\end{tabular}

Note: All descriptive statistics are adjusted to the data when included in regressions using the restricted model. 
Table 6: Restricted model, random effects.

\begin{tabular}{|c|c|c|c|c|c|c|c|c|}
\hline & $\begin{array}{c}(6.1) \\
\text { Clientelism } \\
\text { Index } \\
\end{array}$ & $\begin{array}{c}\text { (6.2) } \\
\text { Vote buying }\end{array}$ & $\begin{array}{c}\text { (6.3) } \\
\text { Party-voter } \\
\text { linkages }\end{array}$ & $\begin{array}{c}(6.4) \\
\text { Particularistic } \\
\text { spending }\end{array}$ & $\begin{array}{c}(6.5) \\
\text { Clientelism } \\
\text { Index } \\
\end{array}$ & $\begin{array}{c}\text { (6.6) } \\
\text { Vote buying }\end{array}$ & $\begin{array}{c}(6.7) \\
\text { Party-voter } \\
\text { linkages } \\
\end{array}$ & $\begin{array}{c}(6.8) \\
\text { Particularistic } \\
\text { spending }\end{array}$ \\
\hline \multirow[t]{2}{*}{ EMB Capacity (Lag1) } & $-0.053 * * *$ & $-0.338 * * *$ & $-0.206^{* * *}$ & $-0.311 * * *$ & & & & \\
\hline & $(0.011)$ & $(0.081)$ & $(0.063)$ & $(0.064)$ & & & & \\
\hline \multirow[t]{2}{*}{ EMB Capacity (Lag5) } & & & & & $-0.041 * * *$ & $-0.268^{* * *}$ & $-0.150^{* * *}$ & $-0.234 * * *$ \\
\hline & & & & & $(0.011)$ & $(0.073)$ & $(0.056)$ & $(0.057)$ \\
\hline \multirow[t]{2}{*}{ Liberal component } & -0.093 & 0.502 & $-0.926^{* * *}$ & $-0.997 * * *$ & $-0.132^{* *}$ & 0.304 & $-1.117^{* * *}$ & $-1.254^{* * *}$ \\
\hline & $(0.058)$ & $(0.426)$ & $(0.283)$ & $(0.363)$ & $(0.057)$ & $(0.428)$ & $(0.267)$ & $(0.351)$ \\
\hline \multirow[t]{2}{*}{ GDP per capita Log } & $-0.043^{* * *}$ & $-0.253^{* * *}$ & $-0.197 * * *$ & $-0.212 * * *$ & $-0.048^{* * *}$ & $-0.276^{* * *}$ & $-0.224 * * *$ & $-0.247^{* * *}$ \\
\hline & $(0.010)$ & $(0.062)$ & $(0.045)$ & $(0.052)$ & $(0.010)$ & $(0.066)$ & $(0.045)$ & $(0.054)$ \\
\hline \multirow[t]{2}{*}{ GDP growth } & $0.031^{* * *}$ & 0.031 & $0.162^{* * *}$ & -0.059 & $0.028^{* * *}$ & -0.052 & $0.159^{* * *}$ & -0.057 \\
\hline & $(0.011)$ & $(0.146)$ & $(0.061)$ & $(0.073)$ & $(0.010)$ & $(0.145)$ & $(0.060)$ & $(0.076)$ \\
\hline \multirow[t]{2}{*}{ Constant } & $0.926 * * *$ & $2.190^{* * *}$ & $2.235^{* * *}$ & $1.606^{* * *}$ & $0.986^{* * *}$ & $2.452^{* * *}$ & $2.540^{* * *}$ & $1.996 * * *$ \\
\hline & $(0.090)$ & $(0.535)$ & $(0.405)$ & $(0.467)$ & $(0.092)$ & $(0.570)$ & $(0.399)$ & $(0.478)$ \\
\hline R2-within & 0.322 & 0.176 & 0.295 & 0.373 & 0.304 & 0.158 & 0.285 & 0.348 \\
\hline R2-between & 0.553 & 0.383 & 0.448 & 0.412 & 0.527 & 0.373 & 0.413 & 0.415 \\
\hline R2-overall & 0.535 & 0.378 & 0.472 & 0.437 & 0.526 & 0.372 & 0.462 & 0.429 \\
\hline Countries & 163 & 161 & 163 & 163 & 163 & 161 & 163 & 163 \\
\hline Observations & 12091 & 3159 & 12091 & 12092 & 11942 & 3114 & 11942 & 11943 \\
\hline
\end{tabular}

Note: All regressions run with robust standard errors and random effects. Model 2 and 6 has fewer observations as vote buying is only measured at elections years. ${ }^{*} \mathrm{p}<0.10, * * \mathrm{p}<0.05, * * * \mathrm{p}<0.01$ 


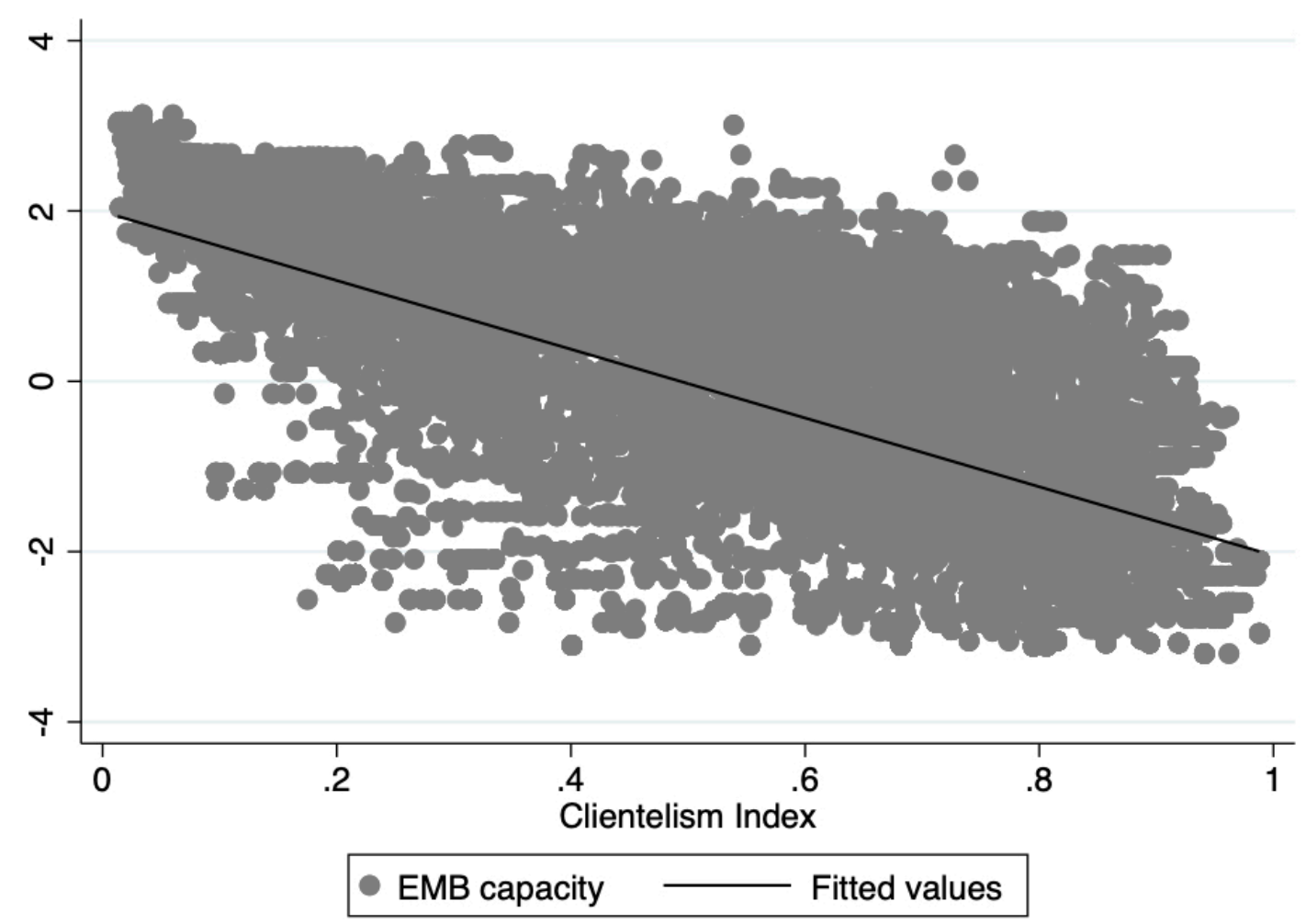

Figure 2. Correlation plot EMB capacity and clientelism 
Table 7: Restricted model, regional samples

\begin{tabular}{|c|c|c|c|c|c|c|c|}
\hline & $\begin{array}{c}\text { (7.1) } \\
\text { Clientelism } \\
\text { Index } \\
\text { Full Sample }\end{array}$ & $\begin{array}{c}(7.2) \\
\text { Clientelism } \\
\text { Index } \\
\text { Eastern } \\
\text { Europe \& } \\
\text { Central Asia }\end{array}$ & $\begin{array}{c}(7.3) \\
\text { Clientelism } \\
\text { Index } \\
\text { Latin America } \\
\text { \& Caribbean }\end{array}$ & $\begin{array}{c}(7.4) \\
\text { Clientelism } \\
\text { Index } \\
\text { Middle East \& } \\
\text { North Africa }\end{array}$ & $\begin{array}{c}\text { (7.5) } \\
\text { Clientelism } \\
\text { Index } \\
\text { Sub-Saharan } \\
\text { Africa }\end{array}$ & $\begin{array}{c}(7.6) \\
\text { Clientelism } \\
\text { Index } \\
\text { Western } \\
\text { Europe \& } \\
\text { North } \\
\text { America } \\
\end{array}$ & $\begin{array}{c}(7.7) \\
\text { Clientelism } \\
\text { Index } \\
\text { Asia \& Pacific }\end{array}$ \\
\hline \multirow[t]{2}{*}{ EMB Capacity (Lag1) } & $-0.052^{* * *}$ & $-0.108 * *$ & -0.032 & -0.007 & -0.033 & $-0.099 * * *$ & -0.019 \\
\hline & $(0.012)$ & $(0.040)$ & $(0.023)$ & $(0.016)$ & $(0.020)$ & $(0.026)$ & $(0.026)$ \\
\hline \multirow[t]{2}{*}{ Liberal component } & -0.089 & $0.253^{*}$ & -0.103 & $-0.346^{* * *}$ & -0.121 & $-0.190 * * *$ & $-0.281 * *$ \\
\hline & $(0.058)$ & $(0.127)$ & $(0.064)$ & $(0.084)$ & $(0.111)$ & $(0.062)$ & $(0.122)$ \\
\hline \multirow[t]{2}{*}{ GDP per capita Log } & $-0.044^{* * *}$ & -0.049 & $-0.097 * *$ & 0.003 & -0.013 & $-0.028^{* *}$ & -0.048 \\
\hline & $(0.010)$ & $(0.038)$ & $(0.040)$ & $(0.019)$ & $(0.016)$ & $(0.013)$ & $(0.029)$ \\
\hline \multirow[t]{2}{*}{ GDP growth } & $0.031 * * *$ & $0.086^{*}$ & 0.026 & $0.028^{* * *}$ & 0.002 & $0.072^{* * *}$ & 0.058 \\
\hline & $(0.011)$ & $(0.051)$ & $(0.035)$ & $(0.010)$ & $(0.017)$ & $(0.020)$ & $(0.044)$ \\
\hline \multirow[t]{2}{*}{ Constant } & $0.921 * * *$ & $0.817^{* * *}$ & $1.500 * * *$ & $0.708^{* * *}$ & $0.709 * * *$ & $0.778 * * *$ & $1.041^{* * *}$ \\
\hline & $(0.089)$ & $(0.289)$ & $(0.331)$ & $(0.164)$ & $(0.135)$ & $(0.121)$ & $(0.206)$ \\
\hline R2-within & 0.322 & 0.308 & 0.462 & 0.152 & 0.112 & 0.735 & 0.385 \\
\hline R2-between & 0.547 & 0.344 & 0.759 & 0.174 & 0.314 & 0.751 & 0.085 \\
\hline R2-overall & 0.533 & 0.289 & 0.582 & 0.242 & 0.223 & 0.731 & 0.237 \\
\hline Countries & 163 & 29 & 23 & 20 & 46 & 24 & 21 \\
\hline Observations & 12091 & 1184 & 2306 & 1158 & 3080 & 2573 & 1790 \\
\hline
\end{tabular}

Note: All regressions run with robust standard errors and fixed effects. ${ }^{*} \mathrm{p}<0.10,{ }^{* *} \mathrm{p}<0.05,{ }^{* * *} \mathrm{p}<0.01$ 


\begin{tabular}{lccc}
\hline & $\begin{array}{c}(8.1) \\
\text { Clientelism Index } \\
\text { W/O Western Europe } \\
\text { \& North America }\end{array}$ & $\begin{array}{c}(8.2) \\
\text { Clientelism Index } \\
\text { W/O Eastern Europe \& } \\
\text { Central Asia }\end{array}$ & $\begin{array}{c}(8.3) \\
\text { Clientelism Index } \\
\text { W/O Western Europe \& North } \\
\text { America, Eastern Europe \& } \\
\text { Central Asia }\end{array}$ \\
\hline EMB Capacity (Lag1) & $-0.048^{* * *}$ & $-0.038^{* * *}$ & $-0.033^{* * *}$ \\
Liberal component & $(0.012)$ & $(0.010)$ & $(0.011)$ \\
& -0.055 & $-0.192^{* * *}$ & $-0.167^{* * *}$ \\
GDP per capita Log & $(0.063)$ & $(0.048)$ & $(0.053)$ \\
GDP growth & $-0.040^{* * *}$ & $-0.047^{* * *}$ & $-0.044^{* * *}$ \\
Constant & $(0.014)$ & $(0.010)$ & $(0.014)$ \\
& $0.025^{* *}$ & $0.032^{* * *}$ & $0.025^{* *}$ \\
R2-within & $(0.011)$ & $(0.010)$ & $(0.011)$ \\
R2-between & $0.917 * * *$ & $0.993^{* * *}$ & $1.006^{* * *}$ \\
R2-overall & $(0.114)$ & $(0.087)$ & $(0.113)$ \\
Countries & 0.245 & 0.363 & 0.280 \\
Observations & 0.353 & 0.561 & 0.210 \\
\hline Note & 0.312 & 0.562 & 0.274 \\
& 139 & 134 & 110 \\
& 9518 & 10907 & 8334 \\
\hline
\end{tabular}

Note: All regressions run with robust standard errors and fixed effects. ${ }^{*} \mathrm{p}<0.10,{ }^{* *} \mathrm{p}<0.05,{ }^{* * *} \mathrm{p}<0.01$ 
Table 9. Restricted model, temporal subsamples.

\begin{tabular}{|c|c|c|c|c|}
\hline & $\begin{array}{c}(9.1) \\
\text { Clientelism Index } \\
\text { 1946-2016 }\end{array}$ & $\begin{array}{c}(9.2) \\
\text { Clientelism Index } \\
1974-2016\end{array}$ & $\begin{array}{c}(9.3) \\
\text { Clientelism Index } \\
1946-2016\end{array}$ & $\begin{array}{c}(9.4) \\
\text { Clientelism Index } \\
1974-2016\end{array}$ \\
\hline \multirow[t]{2}{*}{ EMB Capacity (Lag1) } & $-0.052 * * *$ & $-0.044 * * *$ & & \\
\hline & $(0.013)$ & $(0.014)$ & & \\
\hline \multirow[t]{2}{*}{ EMB Capacity (Lag5) } & & & $-0.038^{* * *}$ & $-0.034 * * *$ \\
\hline & & & $(0.012)$ & $(0.012)$ \\
\hline \multirow[t]{2}{*}{ Liberal component } & $-0.111^{*}$ & -0.067 & $-0.154 * *$ & -0.098 \\
\hline & $(0.062)$ & $(0.067)$ & $(0.061)$ & $(0.064)$ \\
\hline \multirow[t]{2}{*}{ GDP per capita Log } & $-0.022^{* *}$ & -0.018 & $-0.025^{* *}$ & -0.018 \\
\hline & $(0.011)$ & $(0.012)$ & $(0.011)$ & $(0.013)$ \\
\hline \multirow[t]{2}{*}{ GDP growth } & $0.040^{* * *}$ & $0.051^{* * *}$ & $0.035^{* * *}$ & $0.035^{* *}$ \\
\hline & $(0.012)$ & $(0.018)$ & $(0.011)$ & $(0.014)$ \\
\hline \multirow[t]{2}{*}{ Constant } & $0.748^{* * *}$ & $0.692^{* * *}$ & $0.789 * * *$ & $0.701 * * *$ \\
\hline & $(0.098)$ & $(0.116)$ & $(0.102)$ & $(0.121)$ \\
\hline R2-within & 0.225 & 0.144 & 0.202 & 0.127 \\
\hline R2-between & 0.620 & 0.632 & 0.604 & 0.633 \\
\hline R2-overall & 0.537 & 0.546 & 0.529 & 0.551 \\
\hline Countries & 163 & 163 & 163 & 163 \\
\hline Observations & 9964 & 6571 & 9849 & 6485 \\
\hline
\end{tabular}

Note: All regressions run with robust standard errors and fixed effects. ${ }^{*} \mathrm{p}<0.10,{ }^{* *} \mathrm{p}<0.05,{ }^{* * *} \mathrm{p}<0.01$ 


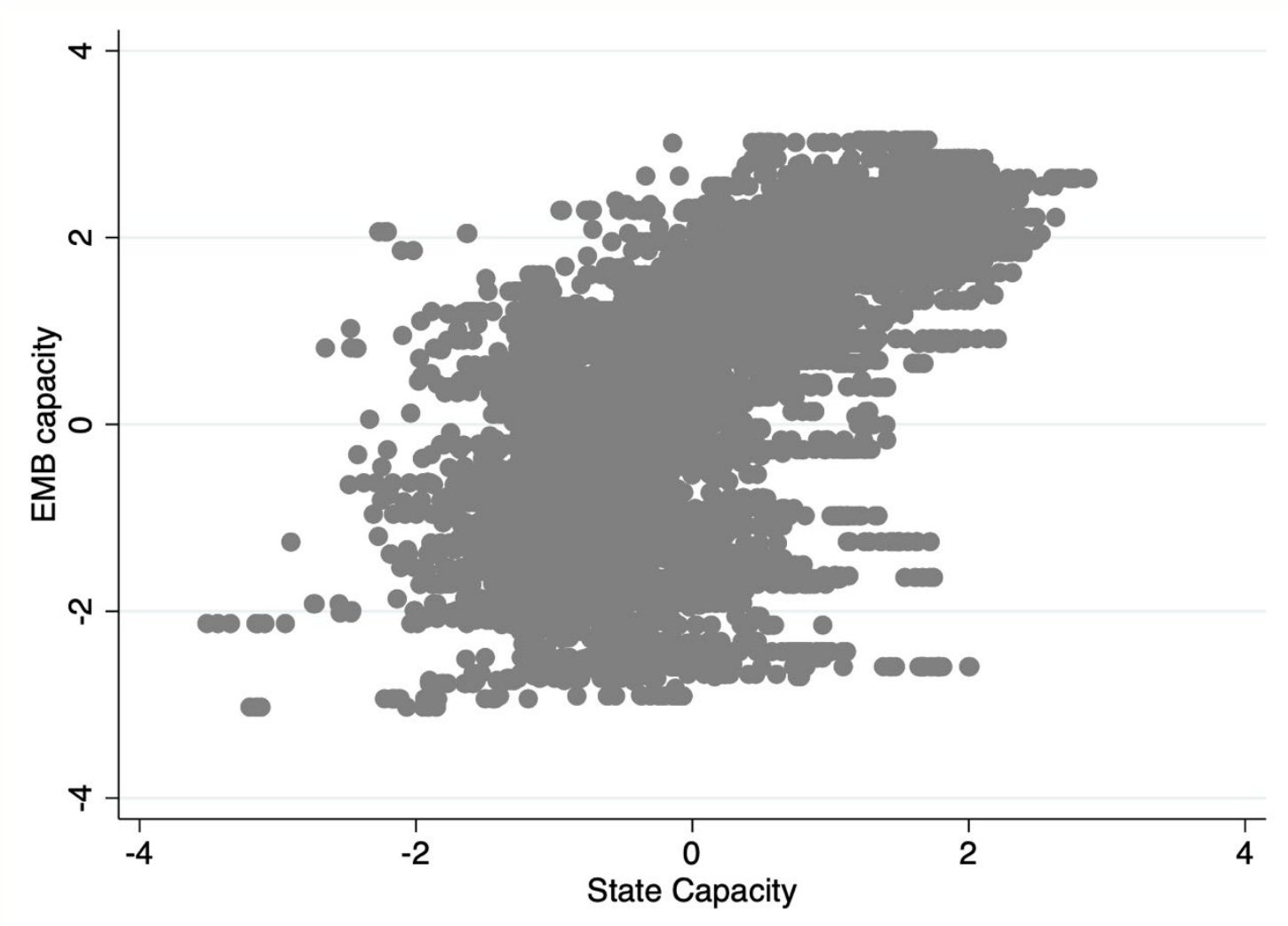

Figure 3. Correlation plot EMB capacity and state capacity

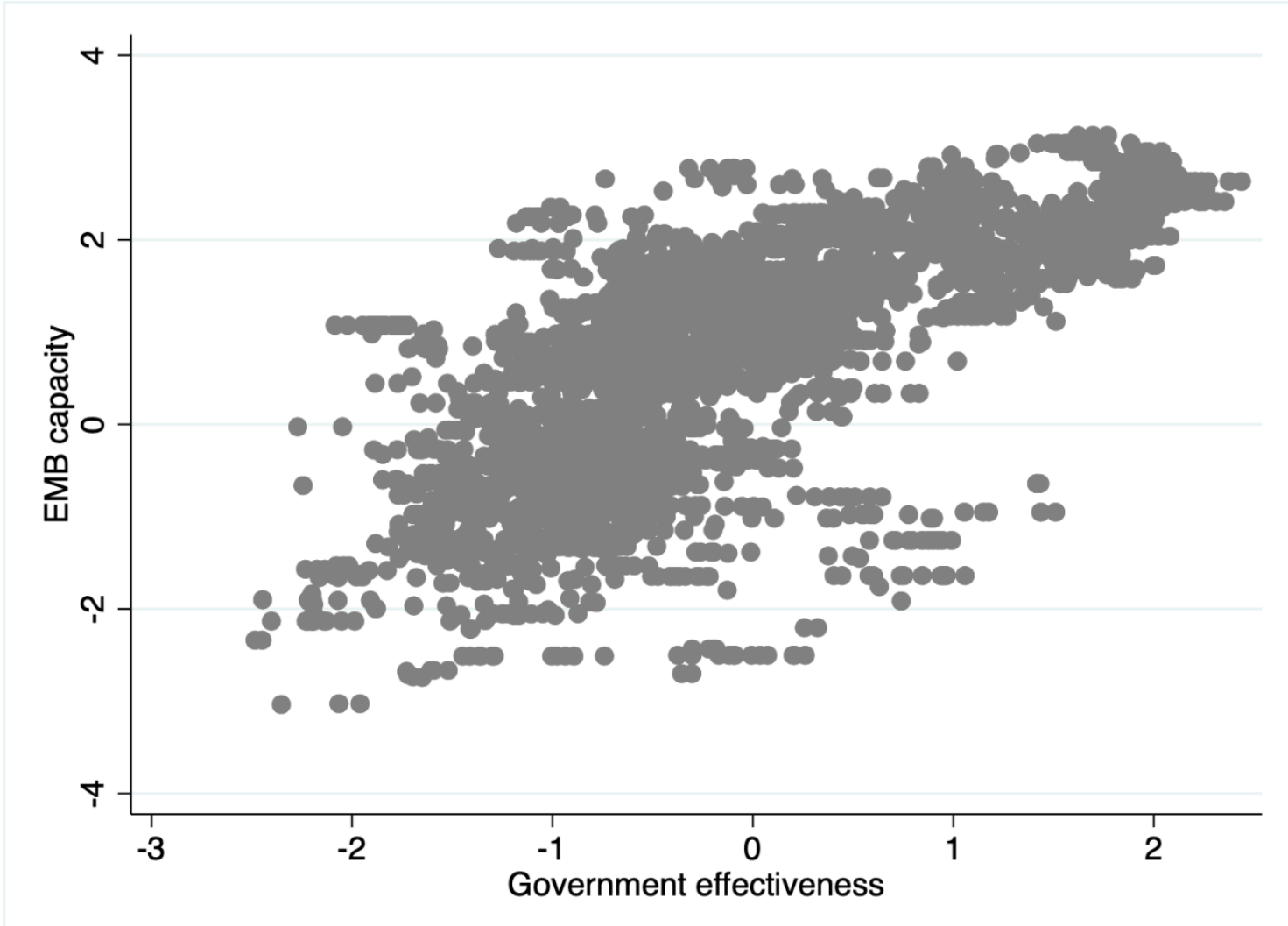

Figure 4. Correlation plot EMB capacity and government effectiveness 
Table 10. Controlling for state capacity and government effectiveness.

\begin{tabular}{|c|c|c|c|c|c|c|}
\hline & $\begin{array}{c}(10.1) \\
\text { Clientelism } \\
\text { Index } \\
\end{array}$ & $\begin{array}{c}(10.2) \\
\text { Clientelism } \\
\text { Index } \\
\end{array}$ & $\begin{array}{c}(10.3) \\
\text { Clientelism } \\
\text { Index } \\
\end{array}$ & $\begin{array}{c}(10.4) \\
\text { Clientelism } \\
\text { Index } \\
\end{array}$ & $\begin{array}{c}(10.5) \\
\text { Clientelism } \\
\text { Index } \\
\end{array}$ & $\begin{array}{c}(10.6) \\
\text { Clientelism } \\
\text { Index } \\
\end{array}$ \\
\hline \multirow[t]{2}{*}{ EMB Capacity (Lag1) } & $-0.051 * * *$ & & $-0.064 * * *$ & & $-0.033^{* * *}$ & \\
\hline & $(0.015)$ & & $(0.016)$ & & $(0.013)$ & \\
\hline \multirow[t]{2}{*}{ EMB Capacity (Lag5) } & & $-0.035^{* * *}$ & & $-0.034 * * *$ & & -0.013 \\
\hline & & $(0.012)$ & & $(0.010)$ & & $(0.009)$ \\
\hline \multirow[t]{2}{*}{ State capacity } & -0.009 & $-0.018^{*}$ & -0.003 & -0.008 & & \\
\hline & $(0.010)$ & $(0.010)$ & $(0.011)$ & $(0.012)$ & & \\
\hline \multirow[t]{2}{*}{ Government effectiveness } & & & & & 0.019 & 0.017 \\
\hline & & & & & $(0.017)$ & $(0.017)$ \\
\hline \multirow[t]{2}{*}{ Constant } & $0.731 * * *$ & $0.720 * * *$ & $0.938 * * *$ & $0.941 * * *$ & $0.685^{* * *}$ & $0.717 * * *$ \\
\hline & $(0.151)$ & $(0.158)$ & $(0.201)$ & $(0.220)$ & $(0.101)$ & $(0.104)$ \\
\hline R2-within & 0.190 & 0.165 & 0.249 & 0.204 & 0.160 & 0.140 \\
\hline R2-between & 0.592 & 0.599 & 0.359 & 0.311 & 0.541 & 0.491 \\
\hline R2-overall & 0.536 & 0.539 & 0.363 & 0.304 & 0.514 & 0.466 \\
\hline Countries & 153 & 152 & 131 & 131 & 163 & 163 \\
\hline Observations & 6648 & 6565 & 4514 & 4511 & 2914 & 2908 \\
\hline
\end{tabular}

Note: All regressions run with robust standard errors and fixed effects. Model 1-2 and 5-6 use the restricted set of controls, model 3-4 use the extended set of controls. ${ }^{*} \mathrm{p}<0.10,{ }^{* *} \mathrm{p}<0.05,{ }^{* * *} \mathrm{p}<0.01$ 
Table 11. Restricted model, alternative measures of clientelism.

\begin{tabular}{|c|c|c|c|c|c|}
\hline & $\begin{array}{c}\text { (11.1) } \\
\text { IEM } \\
\text { Vote Buying } \\
\text { OLS } \\
\end{array}$ & $\begin{array}{c}\text { (11.2) } \\
\text { IEM } \\
\text { Vote Buying } \\
\text { RE } \\
\end{array}$ & $\begin{array}{c}\text { (11.3) } \\
\text { Afrobarometer } \\
\text { Experience of } \\
\text { Vote Buying }\end{array}$ & $\begin{array}{l}\text { (11.4) } \\
\text { Afrobarometer } \\
\text { Perceptions of } \\
\text { Vote Buying }\end{array}$ & $\begin{array}{c}(11.5) \\
\text { WVS } \\
\text { Perceptions of } \\
\text { Vote Buying } \\
\end{array}$ \\
\hline \multirow[t]{2}{*}{ EMB Capacity (Lag1) } & $-0.634 * *$ & $-0.746^{* *}$ & -0.222 & -0.174 & -0.396 \\
\hline & $(0.278)$ & $(0.353)$ & $(0.182)$ & $(0.174)$ & $(0.250)$ \\
\hline \multirow[t]{2}{*}{ Liberal component } & 0.444 & 0.848 & -0.294 & $1.042^{*}$ & 0.588 \\
\hline & $(0.816)$ & $(0.971)$ & $(0.806)$ & $(0.633)$ & $(0.768)$ \\
\hline \multirow[t]{2}{*}{ GDP per capita Log } & -0.318 & -0.372 & $-0.444 * * *$ & $0.243^{*}$ & -0.183 \\
\hline & $(0.373)$ & $(0.425)$ & $(0.171)$ & $(0.135)$ & $(0.299)$ \\
\hline \multirow[t]{2}{*}{ GDP growth } & 1.894 & 2.535 & $-4.500^{*}$ & -2.280 & -1.556 \\
\hline & $(1.748)$ & $(1.753)$ & $(2.643)$ & $(2.768)$ & $(1.478)$ \\
\hline Countries & 58 & 58 & 34 & 36 & 42 \\
\hline Observations & 149 & 149 & 50536 & 49017 & 51120 \\
\hline
\end{tabular}

Note: All regressions are run with robust standard errors. Model 1 uses pooled OLS with an ordinal dependent variable. Model 2 uses TSCS random effects estimation with an ordinal dependent variable. Model 3-5 uses multilevel estimations using an ordinal dependent variable. * $\mathrm{p}<0.10,{ }^{* *} \mathrm{p}<0.05, * * * \mathrm{p}<0.01$ 
Table 12. Restricted model, alternative measures of EMB Capacity

\begin{tabular}{lcccc}
\hline & $(12.1)$ & $(12.2)$ & $(12.3)$ & $(12.4)$ \\
& Clientelism Index & Clientelism Index & Clientelism Index & Clientelism Index \\
\hline PEI Electoral Management & $-0.060^{* * *}$ & & & \\
QED Pre-Election Capacity & $(0.005)$ & & & \\
QED Election Day Capacity & & $(0.007)$ & -0.014 & -0.014 \\
& & & $(0.041)$ & $(0.041)$ \\
Garnett EMB Capacity & & & $-0.440^{* * *}$ \\
Liberal component & & & $(0.091)$ \\
GDP per capita Log & $-0.218^{* * *}$ & $-0.245^{* * *}$ & $-0.244 * * *$ & $-0.092^{* * *}$ \\
& $(0.036)$ & $(0.052)$ & $(0.054)$ & $(0.024)$ \\
GDP growth & $-0.056^{* * *}$ & $-0.055^{* * *}$ & $-0.054^{* * *}$ & 0.126 \\
Constant & $(0.006)$ & $(0.020)$ & $(0.020)$ & $(0.496)$ \\
\hline R2 & $-0.282^{* *}$ & 0.040 & 0.048 & $1.603^{* * *}$ \\
Countries & $(0.118)$ & $(0.035)$ & $(0.037)$ & $(0.176)$ \\
\hline
\end{tabular}

Note: Regressions are run with robust standard errors. Model 1 and 4 uses pooled OLS. Model 2 and 3 are TSCS models using fixed effects. Overall R2 reported for TSCS models. ${ }^{*} \mathrm{p}<0.10,{ }^{* *} \mathrm{p}<0.05,{ }^{* * *} \mathrm{p}<0.01$ 
Table 13. Controlling for corruption.

\begin{tabular}{|c|c|c|c|c|c|c|}
\hline & $\begin{array}{c}(13.1) \\
\text { Clientelism } \\
\text { Index } \\
\end{array}$ & $\begin{array}{c}(13.2) \\
\text { Clientelism } \\
\text { Index }\end{array}$ & $\begin{array}{c}(13.3) \\
\text { Clientelism } \\
\text { Index } \\
\end{array}$ & $\begin{array}{c}(13.4) \\
\text { Clientelism } \\
\text { Index } \\
\end{array}$ & $\begin{array}{c}(13.5) \\
\text { Clientelism } \\
\text { Index }\end{array}$ & $\begin{array}{c}(13.6) \\
\text { Clientelism } \\
\text { Index }\end{array}$ \\
\hline \multirow[t]{2}{*}{ EMB Capacity (Lag1) } & $-0.050 * * *$ & & $-0.043 * * *$ & & $-0.031 * *$ & \\
\hline & $(0.008)$ & & $(0.011)$ & & $(0.013)$ & \\
\hline \multirow[t]{2}{*}{ EMB Capacity (Lag5) } & & $-0.041 * * *$ & & $-0.020^{* * *}$ & & -0.010 \\
\hline & & $(0.007)$ & & $(0.007)$ & & $(0.009)$ \\
\hline \multirow[t]{2}{*}{ Corruption index } & $0.488^{* * *}$ & $0.493 * * *$ & $0.449 * * *$ & $0.467 * * *$ & & \\
\hline & $(0.042)$ & $(0.044)$ & $(0.051)$ & $(0.056)$ & & \\
\hline \multirow[t]{2}{*}{ Control of Corruption } & & & & & $-0.030^{*}$ & -0.031 \\
\hline & & & & & $(0.018)$ & $(0.019)$ \\
\hline \multirow[t]{2}{*}{ Constant } & $0.683^{* * *}$ & $0.726^{* * *}$ & $0.691 * * *$ & $0.707 * * *$ & $0.639 * * *$ & $0.678^{* * *}$ \\
\hline & $(0.073)$ & $(0.076)$ & $(0.101)$ & $(0.110)$ & $(0.102)$ & $(0.104)$ \\
\hline R2-within & 0.514 & 0.499 & 0.446 & 0.424 & 0.164 & 0.146 \\
\hline R2-between & 0.691 & 0.682 & 0.744 & 0.724 & 0.670 & 0.633 \\
\hline $\mathrm{R} 2$-overall & 0.701 & 0.695 & 0.739 & 0.725 & 0.640 & 0.607 \\
\hline Countries & 163 & 163 & 131 & 131 & 163 & 163 \\
\hline Observations & 12086 & 11937 & 5342 & 5334 & 2919 & 2911 \\
\hline
\end{tabular}

Note: All regressions run with robust standard errors and fixed effects. Model 1-2 and 5-6 use the restricted set of controls, model 3-4 use the extended set of controls. ${ }^{*} \mathrm{p}<0.10,{ }^{* *} \mathrm{p}<0.05,{ }^{* * *} \mathrm{p}<0.01$ 


\section{Instrumental Variables}

For reasons of transparency, we report three different instrumental variable approaches that we have tested. The first instrument and the one discussed in the paper (Table A10), uses the regional average (not including the country in question) of EMB capacity as an instrument. The reasoning for this instrument is presented in the article.

The second, found in Table A11, uses the UN population projections dataset to create variables that measures the years since the last census (model 1) and the years since the last census or independence (model 2). The rationale behind this instrument is that a country's statistical capacity and demographic knowledge should affect the conditions for capable electoral management, all the while not likely to be related to clientelism in any way other than through this connection to EMB capacity. The problem with this approach, compared to using the regional average, is that this is a coarse method of assessing statistical capacity/demographic knowledge, that do not capture any nuances within this. Furthermore, it is also possible that the data is influenced by the UN having declared that a country should hold a census at least once a decade, which makes it possible that some countries hold these without it representing, nor them really gaining, statistical capacity/democraphic knowledge.

The third instrument, found in Table A13, uses the proportion of years with EMB capacity as an instrument. This is inspired by Ruiz-Rufino and Birch (2020), who uses proportion of elections with an autonomous EMB as an instrument for EMB autonomy. Following RuizRufino and Birch (2020), we measured a year with EMB capacity as scoring 3 or more on the 0-4 point scale on the ordinal V-Dem measure of EMB capacity (v2elembcap_ord). Model 1 in Table A12 shows this instrument using a 1-year lag, model 2 shows it with a 5-year lag and model 3 with a 10 -year lag. We argue that this approach is less appropriate than using the regional average for two reasons. First, there's the problem of assuming that past EMB capacity should only relate to clientelism through present-day EMB capacity. We cannot know how far back the risk endogeneity persists, and any cutoff in time where it is assumed to be exogenous is arbitrary. Second, the identification of country-years as either having or not having EMB capacity based on the ordinal measure is coarse, and loses significant variation within the continuous variable of EMB capacity.

We thus argue that using the regional average as an instrument both better satisfies the criteria for instrumental variables, and at the same time is not being fraught with any of the estimation problems in the other instruments. Looking at the F-test of the first stage regression, as well as an Anderson \& Rubin-test and Wald-test, in Table A14 also shows that the regional 
average is also the most appropriate instrument in terms of the instrument's relation to the endogenous predictor EMB capacity.

Table 14. IV Regional Average of EMB Capacity.

(14.1)

Clientelism Index

\begin{tabular}{|c|c|}
\hline EMB Capacity (IV) & $\begin{array}{c}-0.063^{* *} \\
(0.028)\end{array}$ \\
\hline Liberal Component & $\begin{array}{l}-0.061 \\
(0.088)\end{array}$ \\
\hline GDP per capita Log & $\begin{array}{c}-0.038^{* *} \\
(0.016)\end{array}$ \\
\hline GDP growth & $\begin{array}{c}0.038^{* * *} \\
(0.009)\end{array}$ \\
\hline Constant & $\begin{array}{c}0.857 * * * \\
(0.161) \\
\end{array}$ \\
\hline R2-within & 0.321 \\
\hline R2-between & 0.568 \\
\hline R2-overall & 0.537 \\
\hline Countries & 163 \\
\hline Observations & 12124 \\
\hline
\end{tabular}

Note: Regression run with robust standard errors and fixed effects. EMB Capacity instrumented with regional average of EMB Capacity. ${ }^{*} \mathrm{p}<0.10,{ }^{* *} \mathrm{p}<0.05,{ }^{* * *} \mathrm{p}<0.01$ 
Table 15. IV Years Since Census.

(15.1)

Clientelism Index

\begin{tabular}{lcc}
\hline EMB capacity (IV) & -0.293 & -0.052 \\
& $(0.200)$ & $(0.067)$ \\
Liberal Component & 0.359 & -0.078 \\
& $(0.361)$ & $(0.158)$ \\
GDP per capita Lag & 0.065 & -0.025 \\
& $(0.072)$ & $(0.028)$ \\
GDP growth & $0.113^{* *}$ & $0.057^{* * *}$ \\
& $(0.047)$ & $(0.017)$ \\
Constant & -0.139 & $0.757^{* * *}$ \\
& $(0.706)$ & $(0.287)$ \\
\hline R2-within & $\cdot$ & 0.203 \\
R2-between & 0.452 & 0.622 \\
R2-overall & 0.395 & 0.554 \\
Countries & 159 & 161 \\
Observations & 7768 & 8947 \\
\hline
\end{tabular}

Note: Regression run with robust standard errors and fixed effects. EMB Capacity instrumented with number of

years since last census (model 1 ) and years since last census or since independence (model 2). ${ }^{*} \mathrm{p}<0.10$, ${ }^{* *}$ $\mathrm{p}<0.05, * * * \mathrm{p}<0.01$

(15.2)

Clientelism Index

$(0.067)$

$(0.158)$

$0.057 * * *$

(0.017)

$0.287)$

0.554 
Table 16. IV Proportion of years with EMB Capacity.

\begin{tabular}{lccc}
\hline & $(16.1)$ & $(16.2)$ & $(16.3)$ \\
& Clientelism Index & Clientelism Index & Clientelism Index \\
\hline EMB capacity (IV) & -0.024 & -0.016 & -0.010 \\
& $(0.031)$ & $(0.048)$ & $(0.080)$ \\
Liberal Component & $-0.147^{*}$ & -0.167 & -0.184 \\
& $(0.080)$ & $(0.112)$ & $(0.178)$ \\
GDP per capita Lag & $-0.060^{* * *}$ & $-0.064^{* *}$ & -0.065 \\
& $(0.019)$ & $(0.028)$ & $(0.044)$ \\
GDP growth & $0.036^{* * *}$ & $0.029^{* * *}$ & $0.025^{* *}$ \\
& $(0.010)$ & $(0.011)$ & $(0.012)$ \\
Constant & $1.079^{* * *}$ & $1.116^{* * *}$ & $1.138^{* * *}$ \\
& $(0.181)$ & $(0.269)$ & $(0.436)$ \\
\hline R2-within & 0.307 & 0.293 & 0.278 \\
R2-between & 0.466 & 0.434 & 0.418 \\
R2-overall & 0.491 & 0.473 & 0.460 \\
Countries & 163.000 & 163.000 & 163.000 \\
Observations & 12069.000 & 11834.000 & 11511.000 \\
\hline
\end{tabular}

Note: Regression run with robust standard errors and fixed effects. EMB Capacity instrumented with proportion of years with EMB Capacity. ${ }^{*} \mathrm{p}<0.10,{ }^{* *} \mathrm{p}<0.05,{ }^{* * *} \mathrm{p}<0.01$ 
Table A13. Tests Instrumental Variable

\begin{tabular}{l|c|cc|ccc}
\hline & $\begin{array}{c}\text { Regional } \\
\text { Average }\end{array}$ & \multicolumn{2}{|c|}{ Years Since Census } & \multicolumn{3}{c}{ Proportion of Years With EMB } \\
Capacity
\end{tabular}

